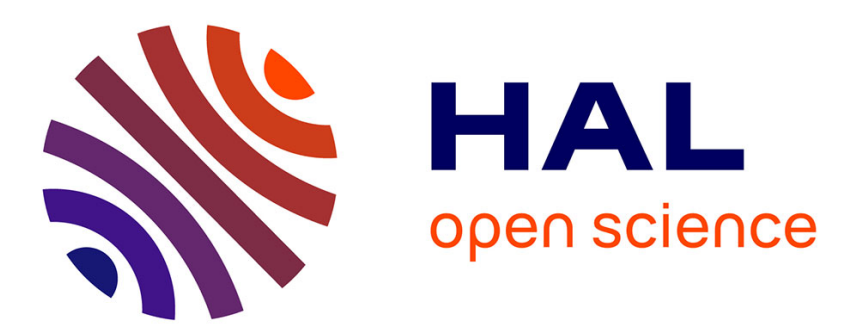

\title{
The Effect of the Arab Spring on the Preferences for Redistribution in Egypt
}

\author{
Bilal El Rafhi, Alexandre Volle
}

\section{To cite this version:}

Bilal El Rafhi, Alexandre Volle. The Effect of the Arab Spring on the Preferences for Redistribution in Egypt. ADRES Doctoral conference 2019, AMSE. Aix-Marseille School of Economics, Feb 2019, Marseille, France. hal-02101392

\section{HAL Id: hal-02101392 https://hal.science/hal-02101392}

Submitted on 16 Apr 2019

HAL is a multi-disciplinary open access archive for the deposit and dissemination of scientific research documents, whether they are published or not. The documents may come from teaching and research institutions in France or abroad, or from public or private research centers.
L'archive ouverte pluridisciplinaire HAL, est destinée au dépôt et à la diffusion de documents scientifiques de niveau recherche, publiés ou non, émanant des établissements d'enseignement et de recherche français ou étrangers, des laboratoires publics ou privés. 


\title{
The Effect of the Arab Spring on the Preferences for Redistribution in Egypt*
}

\author{
Bilal El Rafhi ${ }^{\dagger 1}$ and Alexandre Volle ${ }^{\ddagger 1}$ \\ ${ }^{1}$ CEE-M, Univ.Montpellier, CNRS, INRA, SupAgro, Montpellier, France
}

December 4, 2018

\begin{abstract}
The present paper investigates the effect of the revolution occurred in January 2011 in Egypt on the Preferences of Redistribution. This shock has been an important event enhancing the freedom situation and political structure. In a first step taking into account the main determinants explaining Preferences of Redistribution displayed in literature, our results differ showing a positive impact of the religion and a negative impact of the altruistic attitude. In a second step, we rely on a diff-in-diff approach to estimate the effect of the revolution using as control group three similar countries. We find that Egyptians became much more favorable to redistribution after the Arab Spring. Moreover, the revolution effect is stronger for the poorest people and those who are interested in politics.
\end{abstract}

JEL Classification: H23, D74.

Keywords: Redistributive preferences, Revolution, Arab spring, Freedom, Political situation.

\section{Introduction}

As shown in the world inequality report (W.I.R) the income inequality measured by the concentration of income in the hands of the wealthiest $10 \%$ has increased since 1980 in nearly

\footnotetext{
${ }^{*}$ This paper forms part of the research project RediPref (Contract ANR-15-CE26-0004) of the French National Agency for Research (ANR) whose financial support is gratefully acknowledged. It has also been supported by LabEx Entrepreneurship (Contract ANR-10-LABX-11-01).

${ }^{\dagger}$ Email : bilal.el-rafhi@umontpellier.fr

${ }^{\ddagger}$ Email : alexandre.volle@umontpellier.fr
} 
all world regions (Alvaredo, Chancel, Piketty, Saez, and Zucman (2018)). Understanding the determinants of the preferences for redistribution presents a key topic in the fight against these inequalities. Many motivations drive this attitude as explained by many scholars (Fong, 2001; Corneo and Grüner, 2002; Alesina and Giuliano, 2009). One of the interest aspects in this topic is the political regime under which individuals can express their preferences (Acemoglu, Naidu, Restrepo, and Robinson (2015)). Schläpfer, Schmitt, and Roschewitz (2008) showed how the preferences of citizens could be influenced by political institutions, Kymlicka (2004) in turn stresses the importance of the political liberties in the individual economic attitudes.

In this paper, we are interested in the possible impact of a change in the political regime and in the level of political and informational freedom on the preferences for redistribution, with an application in the case of the Egyptian Revolution. The 25 January revolution which belongs to the Arab Spring, has been an important part of a revolutionary wave where many democratic ideas were spreading. This wave started on 17 December 2010 in Tunisia and has been spread in different forms in many Arab countries like Egypt, Yemen, Libya, Morocco, Jordan and Lebanon. In Egypt, where the most popular slogan was "Bread, Freedom, Social Justice", the revolution succeed, the political regime changed and many shifts occurred at the freedom and political levels. Between 2011 and the first half of 2012 a lot of new political parties were created, and many elections were held. If we look to the evolution of the attitudes towards redistribution between 2008 and 2012 in Egypt in Figure 1, we see that the distribution of the variable presenting the demand for redistribution increased drastically between the two periods. Based on World Values Survey (WVS) data, 22\% of the Egyptian population was in favor of the redistribution in 2008, this percentage rose to $59 \%$ in 2012 (Table 2). This evolution not only impacted the poor people but also the rich: for people belonging to the first quintile (the poorest), this percentage increased by $46 \%$, and for people belonging to the fifth quintile (the richest) this percentage increased by $18 \%$.

Individual preferences for redistribution change over time for many reasons, some are related to personal life evolution, others are related to broader events. The subject of the evolution of the demand for redistribution over a short period constitutes one of the most interesting research quests, especially when what we called a "shock" happens whose effects on the demand for redistribution are anticipated. In the field of the study of the shock effect on the redistribution attitude, Olivera (2014) and Kroeger (2014) showed how the European economic crisis increased the support for redistribution. Margalit (2013) was interested in the American Great recession leading to conclude that a personal economic shock like a job loss has a positive effect on the demand for redistribution. Dahlberg, Edmark, and Lundqvist (2012) showed how increasing the number of immigrants to Europe lead to reduce support for redistribution among 


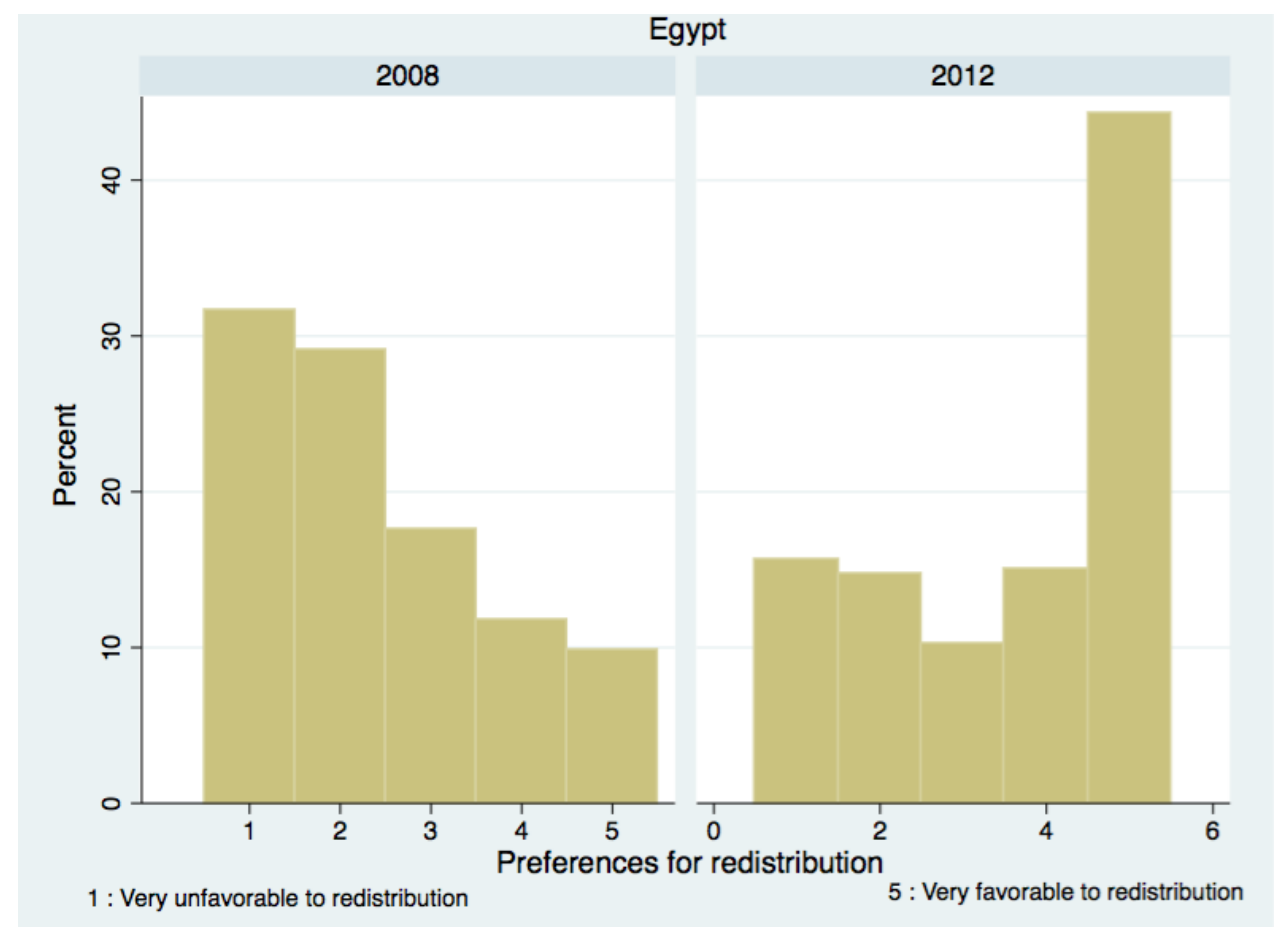

Figure 1: Evolution of the support for redistribution in Egypt between 2008 and 2012

natives in the case of Sweden, and Brunner, Ross, and Washington (2011) studied for California the positive economic shock and found that it reduces the support for redistribution. ${ }^{1}$ Even if the Egyptian revolution is considered as "political" driven and not an as "economic" one like those quoted above, we keep very similar methods, since it remains the effect of time which we are interested in. A significant result for the Egyptian revolution helps us to shed new light on the role of freedom and political offer on preferences for redistribution.

This paper is also the first, to the best of our knowledge, which study the subject of the demand for redistribution in some Arab countries. The Arab world has some characteristics differing it from the developed countries, where most of the researches on demand for redistribution were done. In the first place, about the political situation, Arab countries are considered until now as the most repressive regimes in the World always having the worst ranking in all freedom components (Freedom House (2018)). Elbadawi and Makdisi (2010) talks about a crisis of democracy in the Arab world. In the second place, the whole Arab culture structure has many specificities notably in some important aspects like the particular place of the religion, the relation between the citizens and the government and the vital role of the charitable organisations which would contribute to shape the social preferences differently from other well

\footnotetext{
${ }^{1}$ Dahlberg et al. (2012) explained this result by the fact that more ethnic heterogeneity lead to reduce the demand for redistribution among natives.
} 
studied developed countries (Teti, Abbott, and Cavatorta (2017)). Indeed, many determinants of the support for redistribution are related to cultural dimensions . Therefore, in our study of the effect of revolution, it seems necessary to take stock of the structure of the determinants of the demand for redistribution in Egypt, and therefore control the effects of these factors to isolate the effect of the political change.

The methodology that was adopted in this paper is based on the following idea : if we control for the maximum number of factors that could have an effect on the evolution of the demand for redistribution, the remaining effect of the period between 2008 and 2012 can be considered as the effect of the "political re-foundation" in Egypt. We use in the same line a difference-in-difference approach for the effect of time concerning 3 countries having similarities with Egypt but did not experienced a revolution: Jordan, Morocco and Turkey. We also apply different robustness checks to strengthen our results. Without surprise, the revolution - and therefore the political and the freedom situation change - has a very strong positive effect on the demand for redistribution in Egypt no matter in all the cases. In trying to find convincing explanations binding this result to changes that occurred with the revolution, we study the heterogeneous effect of the revolution over the economic and the political-interested groups. We find that the most affected were the poor individuals and the groups who are the most interested in politics. In the same regressions, we also take care of the effects of the different factors we study in a quest to understand better what characterize Egypt and the 3 other similar countries. In general, at least for Egypt, we have big similarities with literature results especially what relates to the self-interest factors, for example, a better financial situation decreases the support for redistribution. But we also have some particularities for which we search explanations like the positive effect of the religion and the negative effect of being altruist on the preference for redistribution .

The results we obtain along with the reading of the political and freedom situation, guide our interpretation to state that the revolution - after 14 months of its outbreak - enhanced a shift in the collective consciousness about the question of redistribution. This shift is particularly strong for the poorest individuals which means that a part of this change may be related to inequality perception matters. This shift also had a greater impact on the very interested individuals in politics which indicates that the new political speech based in the matter of democracy, social justice and the importance of freedom can be considered as a part of the explanation. In fact, when the level of freedom is very low, the individual faces some inability to make a political decision. In the field of preferences for redistribution, we suppose implicitly that at some threshold of Freedom, individuals can have access to the necessary political and economic information to participate in the political life and therefore know what choices they 
dispose of. It can be considered the case in most of the countries when studies about preferences for redistribution have been lead (mainly in Europe and USA), which was by far not the case in Egypt. In the absence of a minimum level of political and civil liberties, it becomes difficult for individuals to decide how to lead their lives (Kymlicka (2004)). Karshenas, Moghadam, and Alami (2014) stress the attention to the "democratic-developmental social contract" where interest groups discuss on the social justice system, and show how the Arab spring created the conditions for that.

By focusing on the Arab countries and especially Egypt, our study contributes to the growing literature on the determinants of preferences for redistribution by providing the first analysis of these preferences for this region of the world. The second contribution lies in showing the critical role of the informational and political freedom on shaping the support for redistribution. This is achieved by evaluating the effect of the Egyptian revolution on this attitude. We underline that this phenomenon has been rarely studied because the difficulty to have data just before and after a big event like a revolution, which is the case for Egypt.

The remainder of the paper is organized as follows. Section 2 lays out the description of the economic, political and freedom situation before and after the revolution. Section 3 presents the data and the descriptive statistics concerning Egypt and some other Arab countries. In Section 4 we posit the empirical strategy to obtain the results we are looking for. Section 5 presents all results concerning the determinants for demand for redistribution in Egypt, the effect of revolution controlled for these factors, the differential effect of revolution, and the effect of revolution controlled for the Arab trend. In Section 6 we provide some explanations about why the revolution had a positive impact on preferences for redistribution. Finally, Section 7 concludes.

\section{Context : Egypt before and after revolution}

The revolution is a broad popular movement outside the existing constitutional structure, or outside the legitimacy, whose aim is to change the system of government existing in the state as was defined by Azmi Bishara in his book "Revolution and the ability to revolution" written after Arab Spring (Bishara (2009)). According to this definition and other studies Brownlee, Masoud, and Reynolds (2015), the Egyptian social movement was one. This revolution created a strong conscience among Egyptians that the suffering they endure is a result of injustice and it is not a given social situation, and that it is essential to be a free citizen involved in the political life (Bishara (2009)). We are trying in this Section to find what factors could have enough strength to shift the preferences of the individuals as we see for Egypt. For that, we 
will expose the economic, political and freedom situations before and after January 2011, while depicting essentially the consequences the revolution had on two vectors: the political life and the freedom of information.

At the level of the economic situation, we are interested in the most important economic indexes. If we look at the growth rate in table 4, we read that it was increasing since 2004 (The World Bank (2018))(table 4). We take an inequality indicator, the Gini index was slightly improving as we can see in table 4. We note the same trend for the Human Development Index HDI. In the few months directly after the revolution, as Abdou, Salman, and Zaazou (2013) presented in their document, the economic situation was damaged, but apparently not to the point of having an effect on people's financial feelings. Indeed, in our data, the percentage of individuals unsatisfied with their financial situation in 2012 compared to 2008 was almost the same: $42 \%$ in 2008 and 44\%. Costello, Jenkins, and Aly (2015) showed in their discussion on the determinants of the Arab awakenings protests, the limited role of the economic factors on these revolutions, and they found rather good support for the effect of the "state terror", an important element of the freedom, which we discuss in the next paragraphs.

On the eve of the Arab Spring, the Arab world was considered as the most repressive region in the world. Egypt was a part of this reality: from 1981 until the revolution in 2011, Egypt was always considered one of the least free countries. Egyptians were chaired all this time by the same person, the ex-general "Hosni Mubarak". Amnesty international (2011) criticized several times Mubarak administration, for reasons linked to restrictions on freedom of expression and assembly, and also for political censorship. In the political field, only one political party was really existing, the National Democratic Party (NDP), considered as a single party, authoritarian and centrist (El-Mikawy (1999)). The emergency law was maintained during all the duration of Mubarak presidential (Othman (2012)). Freedoms of assembly and association in 2008, 2009 and 2010 were heavily restricted (Freedom house, 2008, 2009, 2010). We also rely on table 3 where is presented the ratings of some freedom components in these years (2008 and 2010).

On 25 January 2011, the 6 April youth movement and others opposition groups called to protest for a day called the "Day of Anger". Demonstrations were maintained in different cities, and the government took a set of steps to fight against it. After 16 days of demonstrations, Hosni Mubarak Vice resigned as president. One of the characteristics of this revolution is that it was popular, people from all social spheres participated (Bishara, 2009; Costello, Jenkins, and Aly, 2015). One of the first claims of the Egyptian people was about restoring dignity and get rid of the restriction of liberties (Dabashi, 2012; Telhami, 2013). This revolution was in line with the revolutionary wave that began in Tunisia in December 2010 and stretched to 
many other Arab countries, a wave called "The Arab Spring". Nevertheless, revolutions have succeeded only in Tunisia and Egypt. The Egyptian revolution was the beginning of a series of changes concerning the social and political life of citizens. Years 2011, 2012 were a particular part of the Egyptian history in term of citizen's participation in political life and the evolution of the freedom situation.

At first, we talk about the evolution of the political life in Egypt: after few months of the revolution, many political parties were created with different economic and ideological programs, parties have succeeded very well in the legislative elections done in the end of 2011 and the beginning of 2012, with the almost disappearance of the old NDP party as we can see in table 6 . In this legislative election, the turnout rate was very high (62\%) compared to the 2010 legislative election $(27,47 \%$ in 2010) as we can see in table 5. In 2012, for the first time in the history in Egypt, the presidential election corresponding the global standards was done, the turnout was also very high compared to the 2005 presidential election $(51.85 \%$ in 2012 and $22.95 \%$ in 2005) (table 5). In addition, there were also one referendum and one consultative council elections. In just two years (2011 and 2012), Egyptian citizens have participated at 3 democratic events. This year (2012) has also seen the lifted of the emergency state after 30 years. One of the most important variables we have in the database showing how the relationship of individuals has changed towards politics, is the degree of interest in politics: the distribution of individuals over the degree of interest in politics changed sharply after the revolution as we can see in Figure 2.

To show the development of the freedom situation at this level, we rely on the Human Freedom Index (HFI) presented in table 3: some indicators improved strongly between 2008 and 2011-2012. The freedom of association and demonstration has increased by three times from 2.5/10 to 7.5/10 (0 means no freedom at all; 10: the best freedom situation), the freedom of assembly and the freedom to establish organizations have also rocketed. Moreover, the NGO "Freedom house" improved the rating of Egypt's political rights in 2012 from "Not Free" to "Partly Free" (Vasquez and Porcnik (2016)).

At second, we talk about the evolution of the freedom of information, by notably highlighting the development of the part linked to Internet. Table 3 reports the evolution of the freedom information in Internet: the state control over Internet access has become much less influential, from 3.3/10 to 7.5/10 (Vasquez and Porcnik (2016)). The same report also mentioned the increasing of the number of independent television stations and the number of newspapers, and the improvement of the Academic Freedom . These social medias were considered as the most important platforms where citizens expressed themselves and where the political parties had 


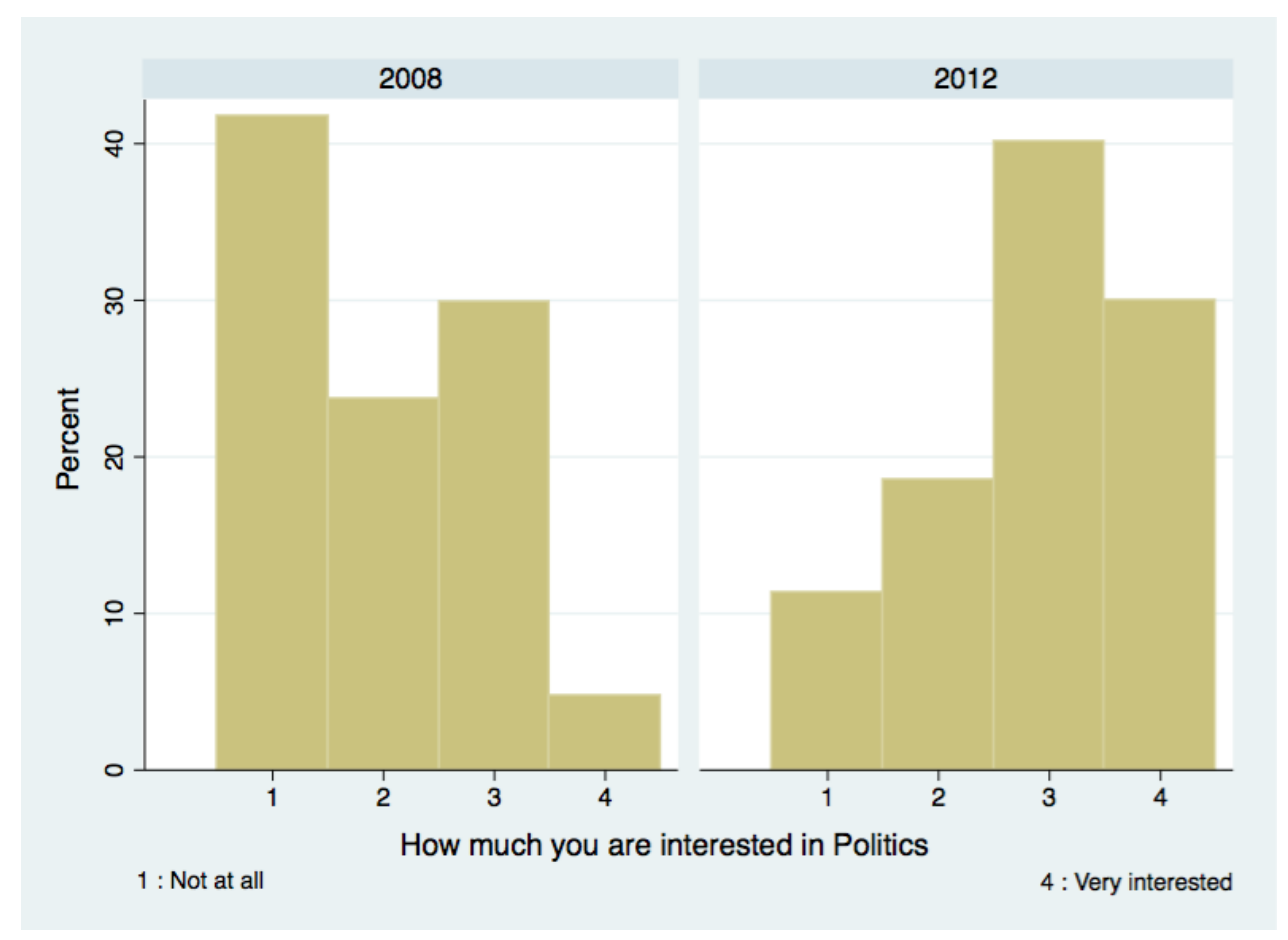

Figure 2: Interest in Politics : Egypt

an independent tool of communication. In fact, the number of Facebook and Twitter users has risen very strongly in the two years after the revolution (Mourtada and Salem (2011)), and Facebook becomes the most popular search queries in Egypt (Wolfsfeld, Segev, and Sheafer (2013)). Many authors showed the positive effect of the social media in organizing the demonstrations and discussing news before the revolution (Lotan, Graeff, Ananny, Gaffney, Pearce, et al. (2011),Stepanova (2011)). This effect remained present after the revolution and played an essential role in shaping political debates, and spreading democratic ideas (Howard, Duffy, Freelon, Hussain, Mari, and Maziad (2011)). As we can see in table 8 that the classical media did not enjoy enough the improvement of Freedom situation, the political pressures and controls on Media content did not change, what pushed citizens to look after social medias (Howard et al. (2011)). Dabashi (2012) explains how news media, essentially social media with the new Internet newspapers, helped in the circulation of knowledge of civil liberties, and how that they were the real theorists of the Arab Spring. 


\section{Data and descriptive statistics}

\subsection{Data}

The data come from the World Values Survey data (WVS). These data consist of nationally representative surveys conducted in almost 100 countries on six waves between 1981 and 2014 . The first wave including Arab countries was the fourth wave (1999-2014). Since we are only interested in the change due to revolutions, we limit our interest on the wave before the Arab Spring and the wave after, to know the wave 5 (2005-2009) and the wave 6 (2010-2014). For Egypt, the wave 5 was conducted between 15 March 2008 and 05 April 2008, and the wave 6 between 01 March 2012 and 30 April 2012.

We can see in table 7 the availability of data for several Arab countries in the waves 5 and 6. We also add Turkey even if it is not an Arab country for the religion, geographical and historical similarities. We can see that we have the data simultaneity before and after Arab revolutions only for five countries: Egypt, Iraq, Jordan, Morocco and Turkey.

For the first part of the study concerning the determinants of preferences for redistribution in Egypt, we rely on the data available for Egypt in the waves 5 and 6 . We also test the effects of these factors on demand for redistribution for other Arab countries in order to help us to explain the results we find for Egypt. For the second part of the study concerning the effect of the Egyptian revolution on demand for redistribution in Egypt, we are relying on the data collected for Egypt, Morocco, Jordan, Turkey for the same period.

\subsection{Descriptive statistics}

In tables 1, 8, 9 and 10, we represent some information about the main individual characteristics of the individuals in the sample before and after January 2011 for Egypt, Jordan, Turkey and Morocco, as well as the financial situation and the attitudinal variables. In table 1, the first three columns refer to the period before the revolution for Egypt (at the beginning of 2008) and the three last columns refer to the period after the revolution for Egypt (14 months after the revolution). The last column in table 1 refers to the maximum value of the correspondent variable, besides the binary variables the minimum value is always 1 . The same design is made for Jordan, Morocco and Turkey with different fieldwork periods. More details can be found in Appendix A.

The size of the samples is between 1000 and 1500, except the 2008 sample for Egypt which 
Table 1: Summary statistics : Egypt

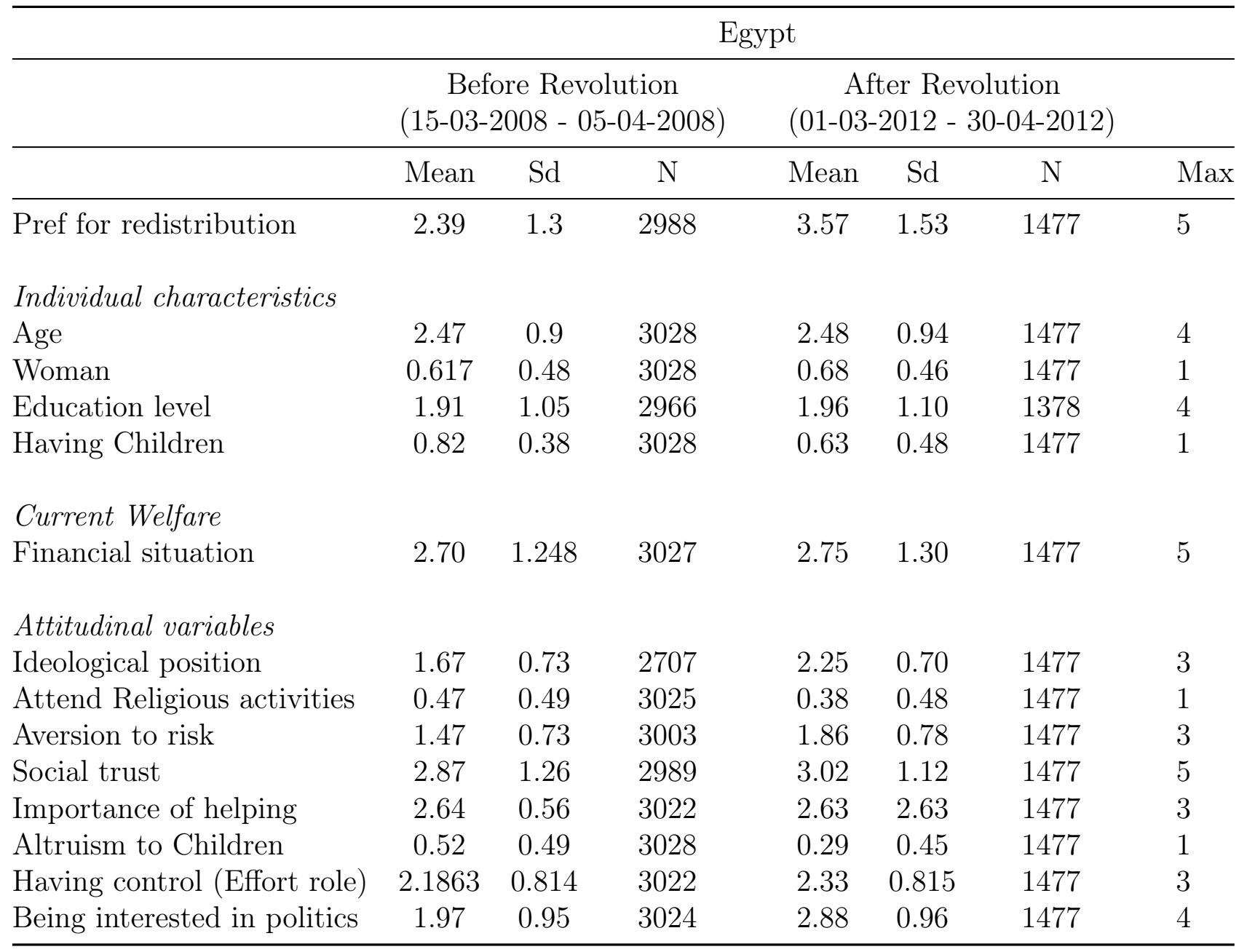

is 3000 individuals. Some variables are missing in some samples which we will take into account our analysis. Concerning the individual characteristics variables across countries before 2011, one notes that they have fairly close means except for the number of womans where is quite highly in Egypt.

Our summary statistics suggest that the individual characteristics remain relatively stable between periods, except for who have one child or more for Egypt and Jordan, which is smaller in Egypt and more prominent in Jordan in wave 6 compared to wave 5. The summary statistics also indicate that the financial situation on average did not change in Egypt between 2008 and 2012, increased in Jordan and Morocco, and slightly increased in Turkey. For the attitudinal variables, some variables means changed considerably in all countries. In Egypt, Individuals became in average more in right ideologically, a little less religious, more risk-averse, more believing that they have control on their life, and much more interested in Politics. In Jordan, 
Individuals became on average less risk-averse, less trustful in society. In Turkey, the Individuals became in average more in right politically, slightly more averse to risk, more trustful in society, more interested in politics. In Morocco, Individuals became on average more trustful in society, less believing that they have control on their life, a little more interested in Politics. We can draw for this changes, that Egypt experienced more changes than the other countries, and especially at the level of the degree of interest in politics compared to the other countries as we can in figures 2 and 4 . The number of individuals interested in politics has increased enormously in 2012. The different trajectories concerning the evolution of these variables in the time, show the need to take control for these variables in the coming sections.

Table 2: Percentages of individuals who are favorable for redistribution before and after January 2011 in the four countries

\begin{tabular}{lcc}
\hline & \% Individuals favorable for redistribution \\
\hline & $2007-2008$ & $2011-2012$ \\
\hline Egypt & $22 \%$ & $59 \%$ \\
Jordan & $25 \%$ & $12 \%$ \\
Morocco & $36 \%$ & $40 \%$ \\
Turkey & $49 \%$ & $55 \%$ \\
\hline
\end{tabular}

We focus now on our explained variable, the one indicating namely the individual preference for redistribution. We rely on this following question in the survey: "I'd like you to tell me your views on various issues. How would you place your views on this scale? 1 means you agree completely with the statement on the left (Incomes should be made more equal) ; 10 means you agree completely with the statement on the right (We need larger income differences as incentives for individual effort); and if your views fall somewhere in between, you can choose any number in between". Responses were coded on a scale of 1 through 5 , with 5 representing being very favorable to the statement "Incomes should be made more equal" (i.e. More favorable to redistribution). This variable was used many times to measure support for redistribution (Murthi and Tiongson, 2008; Shayo, 2009; Klor and Shayo, 2010). As we can see in Figure 1, the distribution of the individuals over the choices concerning the demand for redistribution, changed drastically after the revolution : based on these data, $21.65 \%$ of the Egyptian population was in favor of the redistribution in 2008 (responded 4 or 5), this percentage rose to $59.31 \%$ in 2012 . If we look at figure 3 to the evolution of this percentage in Morocco and Turkey, we found that there was a slight increase, especially if we look to the means of this variable in these two countries. In Jordan, the mean of the demand for redistribution decreased very slightly in 2014, even if the number of individuals declaring 
support for redistribution decreased strongly (from $25 \%$ to $12 \%$ ). We draw from all of this, the importance of studying more deeply this phenomenon by an econometric approach.

\section{Empirical strategy}

Since no study has been done on Arab countries generally and on Egypt specifically in the field of demand for redistribution, the first stage of our empirical strategy is to study the effects of the traditional factors we explored in the Section 3 that might have an effect on the preferences for redistribution in Egypt according to the studies already done on the subject. We compare the results we obtained with those concerning the other Arab countries when it is necessary. It is insightful to do so to validate what is consistent and at the same time pointing out the results which seem to be in contradiction with the current literature.

We assume that the demand for redistribution if individual $i$ living at time $t$ can be characterized by a latent variable $y_{i t}^{*}$. Since we have a discrete ordinal dependent variable, we are using ordered logit model (We assuming a logistic redistribution for the error term). Standard errors are corrected for heteroskedasticity. In Section 1, we use the function 1 to estimate the parameters :

$$
y_{i t}^{*}=\eta \cdot I_{i t}+\beta \cdot S_{i t}+\gamma \cdot A_{i t}+\zeta \cdot R+\varepsilon_{i t}
$$

$y_{i t}^{*}$ is the "latent variable" presenting the preference for redistribution for an individual $i$ living in a year $t ; I_{i t}$ is a vector of the financial situation; $S_{i t}$ is a vector of the individual characteristics; $A_{i t}$ is a vector of the personal social attitudes; $W$ is a wave dummy; and $\varepsilon_{i t}$ is an error term. $\eta, \beta, \gamma$ and $\zeta$ are parameters.

We do not observe $y_{i t}^{*}$ but a variable $y_{i t}$ taking values 1 to 5 increasing in individual demand for redistribution. We have

$$
y_{i t}=m \text { if } \alpha_{m-1}<y_{i t}^{*}<\alpha_{m} \text { for } m=1, \ldots, 5
$$

Where $\alpha_{1}, \alpha_{2}, \alpha_{3}, \alpha_{4}$ are the unknown cut points.

We begin by to assess the sign and significance of the vectors of the coefficients related to the determinants of preferences. Section 5.1 describes the results of this procedure.

The second phase of the analysis consists of studying the effect of the revolution. Given that the Egyptian revolution is the major event that occurred between 2008 and 2012, it can 
be hypothesized that, at least partially, this is what the dummy year is capturing. In first we use the function 1 to evaluate the sign and the significance of $\zeta$ the coefficient capturing the effect of time, which is here the effect of the revolution. In second, we move to study the effect of the revolution in Egypt but this time we include a control group, which is not affected by the revolution, and therefore make a difference in difference. In order to do this, we use the two waves data for the four countries: Egypt, Turkey, Jordan and Morocco. To estimate the effect of the revolution on the Egyptian people in this case we use the function 2 where the demand for redistribution of individual $i$ living in the country $c$ at period $t$ can be characterized by a "latent variable" :

$$
y_{i c t}^{*}=\beta_{1} \cdot I_{i c t}+\beta_{2} \cdot S_{i c t}+\beta_{3} \cdot A_{i c t}+\beta_{4} \cdot R+\beta_{5} \cdot E+\beta_{6} \cdot W \cdot E+\varepsilon_{i c t}
$$

$E$ is a country dummy equal to 1 if the individual lives in Egypt and 0 if he is living otherwise; $W . E$ represents the interaction between $W$ and $E . \quad \beta_{6}$ is the difference-in-difference estimator. We conduct robustness checks using two waves before the revolution instead of 1 .

Finally, we are interested in estimating the differential effect of the revolution on the different socio-economic and attitudinal groups in Egypt by adding the interactions between these groups and the period dummy W. We use the function 3 :

$$
y_{i t}^{*}=\gamma_{1} \cdot I_{i t}+\gamma_{2} \cdot S_{i t}+\gamma_{3} \cdot A_{i t}+\gamma_{4} \cdot W+\gamma_{5} W \cdot I_{i t}+\gamma_{6} W \cdot S_{i t}+\gamma_{7} W \cdot A_{i t}+\varepsilon_{i t}
$$

Where $\gamma_{5}, \gamma_{6}$ and $\gamma_{7}$ are parameters for interaction groups.

\section{$5 \quad$ Results}

\subsection{Determinants of preferences for redistribution in Egypt}

\section{Individual characteristics}

We start our analysis by examining the effect of some individual characteristics on support for redistribution in Egypt. In the existing literature, the older the individual is, the less he is likely to support redistribution (Alesina and La Ferrara, 2005; Alesina and Giuliano, 2009; Busemeyer, 2013). Alesina and Giuliano (2009) found an inverted U curve effect, the demand for redistribution decline in advanced stages of the life-cycles. In the tables 12,13 and 14, we found that the younger people are less favorable to redistribution compared to others, especially compared to the older individuals where the effect is significant. 
Across regressions, we see that being female enhance the desire for redistribution which is consistent with what can be found in the literature (Alesina and Giuliano (2009)).

For the education level, we find that being illiterate or having a very low education level increase the demand for redistribution compared to others (Alesina and Giuliano (2009)). Finally having a child or more, yields no significant effect once controlled by the financial situation (Neher (2011)).

\section{Financial situation}

A large body of empirical evidence shows that the financial situation is one of the most important determinants. The richer a person is, the more he is supposed to be favorable to redistribution (Corneo and Grüner, 2002; Guillaud, 2013). In all columns in table 12 and 13 and 14 we see that individuals living in a good or very good financial situation are much less favorable to the redistribution compared to those living in a bad financial situation. ${ }^{2}$

\section{Health situation}

Being in bad health means more health-related expenses, and puts individuals in a risky situation regarding their future. Therefore this variable can be a proxy for the risk exposure. These elements push individuals to be more favorable to redistribution (Olivera (2015)), which we found in table 13 (column 1).

\section{Ideological position}

In column 2 in table 13, we add an important variable in the literature, the ideological positioning (left-center-right). Being leftist enhance the demand for redistribution compared to those being rightist even if we control it with the financial situation (Busemeyer (2013), Pittau, Farcomeni, and Zelli (2016)).

\section{Reciprocity (Trust)}

We include the variable stating if the individual thinks that the most people can be trusted as a proxy for the reciprocity attitude of the individual. Trusting others will push the individual to think that others will not take something is not their right legally and therefore being more favorable to redistribution compared to those having the opposite attitude (Fong, 2001; Fatica,

\footnotetext{
${ }^{2}$ Variable Financial sit: the felt familial financial situation. 1: Very bad 5: Very good. We have tried two other variables of the financial situation and we had the same results.
} 
2011). The column 3 of table 13, shows that, as expected, that trusting other yields a significant and strong positive effect.

\section{Religion}

In column 4, we talk about being an active participant in religious activities. In the literature, religious people compared to others are less favorable to the redistribution, one of the explanations are that religious people profit more from the services provided by religious helping networks (Luttmer and Singhal, 2011; Neustadt, 2011). In our study, attending religious activities has the opposite effect, the coefficient is positive. One of the explanations remains in the fact that Egyptian society is a very religious one, so we do not have this community effect we can find in the developed countries. Therefore another component of being religious appears, which is the religious education focusing on the importance of asceticism and altruism. In this case, we can understand why the religious persons tend to be more favorable to redistribution. One has to underline we find the same positive effect in many other Arab countries (table 45,46,47) like Algeria, Iraq (significant), Bahrain, Morocco, Lebanon (significant).

\section{Risk aversion}

We also study the effect of the risk attitude, Beck (1994) run an experimental study and found how risk aversion can make the individual more favorable to the redistribution based on an "insurance motive". Rehm (2009) explains by an empirical study how a risky job (where the percentage of unemployment is high) has a positive effect on the demand for redistribution, Alesina and La Ferrara (2005) use proxies like self-employment, that yields a negative effect. In this study, we use individual answers to a question that would elicit the aversion risk: "Is it important to this person adventure and taking risks? 1: Very much like me; 6: Not at all like me. We re-coded it in an increasing way that 1 represents the risk-averse individuals, and the 3 the risk-seeking individuals. We see in column 5 in table 13 that the coefficients are negative which is why it is expected, but the coefficients are insignificant. We tried to study the effect of the risk attitude by taking the institution occupation (if the individual is self-employment or working in public sector or public sector) but only for the wave 6 since we do not have this data for the two waves: the effect still insignificant. We explain this insignificant effect by the fact that the labor market structure is very different in Egypt compared to the developed countries, being in a public institution may do not offer the same insurance that offers the same position in the developed countries. ${ }^{3}$ If we look at the tables 39, 40 and 41, only in Turkey and Iran we have a significant negative coefficient.

\footnotetext{
${ }^{3}$, For example, a big part of the Egyptian people still lives in rural areas, where most of the jobs are considered as self-employment.
} 


\section{Altruism}

To test the effect of altruism, we use a proxy indicates if the individual finds that the unselfishness is an important quality for a child, and another proxy indicates if the person thinks that is it important to help people. In the literature, being altruistic has a positive effect Alesina and La Ferrara (2005). We find in column 1 and 2 of table 14 that for the two proxies, being altruistic has a negative effect and it is very significant. The reason these variable yields the opposite effect, maybe yields in the fact that in a society like the Egyptian one, having an altruistic attitude, reflects that this person is living in an altruistic environment where individuals are less dependent on state help. Indeed, an altruistic behavior in some societies (especially in a rural society like Egypt ${ }^{4}$ ) may reveal a closer social life, where in the case of a financial problem, the individual will in first place ask his entourage for help. Karshenas et al. (2014) explained how in the Arab countries residual forms of social transfers based on the ethnic and religious groups cover the needs not covered by the social state. In other countries like OECD countries or the United-States (countries where most studies have been done), we are talking about different types of society where the requested help is -very often-addressed to the State. If we look to the effect of these variables in other Arab countries (tables 51,52,53,54,55 and 56), we find that the first proxy coefficient is negative and significant in Iraq, Lebanon and Tunisia like in Egypt. We found a positive significant coefficient only in Yemen and Jordan. For the second proxy only in Tunisia, we found a positive effect of being altruism. Which indicates that the explanation of this result lies in something specific to the Arab social structure.

\section{Role of effort : Autonomy freedom}

In column 4 in table 13, we add an important factor considered as one of the most influential determinants of the preferences for redistribution: the belief about the role of effort and chance in determining the success in life. In literature, the more the respondent believes the effort is essential, the more he is against the redistribution compared to the respondent who believes luck is more important. It is also called the fairness attitude. The explanation behind it is that if the effort is what determines our success in life, there is no need anymore for the incomes to be equal : if the individual is in a bad situation, then that is the result of what he sowed (Piketty, 1995; Fong, 2001; Ravallion and Lokshin, 2000) .In our study we take as a proxy for this attitude, the following question: "How much freedom of choice and control you feel you have over the way your life turns out". In fact, if individuals consider that they have control on their life, they will be more able to accept their financial situation as a result of their effort, and

\footnotetext{
${ }^{4} 56 \%$ of the population are living in rural areas.
} 
then less favorable to redistribution. In the last column, we find the expected result: the effect is negative, significant and progressive. We found the same result in almost all Arab countries (table 57,58,59).

\subsection{The effect of the revolution}

Like we stated in the third Section, the distribution of the respondents over the demand for redistribution has changed drastically. To estimate and quantify the effect of this revolution correctly, we control this effect in first for the classical determinants of demand for redistribution within the Egyptian people, and in second for the effect of time that concerns the Arab world generally. We are interested also to see if we have differential revolution effect by groups we choose.

To estimate the effect of revolution, we estimate the effect of time, the effect of living after January 2011 (2012 for Egypt) compared to living before January 2011 (2008 for Egypt). The variable "After revolution" represents a dummy where after $=1$ if the respondent was questioned in the wave 6 and after $=0$ if the respondent was questioned in the wave 5 .

Table 12, 13 and 14 represent the results we obtain by estimating the effect of the Egyptian revolution on demand for redistribution in Egypt adding variables one by one. The variables we add are the same we The baseline estimate (Column [1]), without any controls, shows that on average, living in 2012 is associated with a 0.296 increase in the probability of identifying as very favorable to redistribution and a 0.0183 decrease in identifying as very unfavorable compared with an individual living in 2008. This effect is still significant, very strong and having nearly the same marginal effects after the introduction of each of the variables. We can conclude that changes in individual characteristics, financial situation and the attitude variables, are not able to explain the shift in the redistributive support after the revolution.

\section{Robustness : Diff-in-Diff analysis}

Is the effect of time peculiar to Egypt to say that it was the revolution that caused this change? Or is we can find the same effect for all Arab countries? To answer this question, we rely on the data of Egypt, Jordan, Morocco and Turkey. These countries are quite close at the political and economic level, which provide us a very good control group, and therefore allow us to take into account the parallel trend. 
In first we run the regression following the function 1 for each of these four countries (table 15), and we calculate the marginal effects (table 16). We found that the effect of time in the other countries is very significant. However, once we look at the marginal effects, we notice the immense difference between the values of Egypt and those of other countries. For example, the probability of being very favorable to redistribution in Egypt in 2008 compared to 2012 is $26.8 \%$ higher, only $4.5 \%$ higher in Jordan, $4.3 \%$ in Morocco and $5.5 \%$ in Turkey. This means that to obtain the proper effect of the Egyptian revolution, it will be necessary to isolate the effect of time which affects all countries in consideration. These positive effects of coefficients of time variable indicate that there is a tendency towards more redistribution in the Arab Zone. One of the explanations is that the Arab Spring has touched the majority of the countries slightly even if there was no revolution. The second explanation is that between 2008 and 2012, there was more openness to the international due to the development of the level of education and access to the Internet, and then better information on the situation of inequality.

To obtain the proper effect of the revolution, we calculate the diff-in-diff estimator representing the proper effect of time concerning Egypt based on the function 2. The diff-in-diff estimator is obtained by the interaction between the dummy variable equal to 1 if individual lives in Egypt and 0 otherwise and the number of the wave as we can see in table 17 and 18 . We are looking for the diff-in-diff estimators by taking each time Egypt with one of the countries alone. Even if is the magnitude of the coefficient became smaller, as we can see in the table, the diff-in-diff estimator is very significant and remains strong in any case. In table 18, we can see the coefficient of the diff-in-diff estimator, taking as a control group this time the three countries together. The coefficient is very significant and big. We conclude that even if there is a part of the effect of time is unspecific to Egypt, the effect of the revolution remains very strong.

The second placebo test consists of comparing the effect of time between the waves 5 and 6 to the one we obtain between the waves 4 and 5. Between 2001 and 2008, there was no revolution, the expected result for the effect of time is to have a marginal effect small enough to be compared to that of the period of the revolution. We run the same regression we did (function 1 ) for the wave 4 and 5. The coefficient is very significant: being in 2008 has a positive effect on the support for redistribution compared to being in 2001 (Table 19). However, we calculate the marginal effects (Table 20), and we found that probabilities of being very favorable or favorable for more redistribution are very different between those of 2008-2012 and those of 2000-2008. It is $11.6 \%$ between 2000 and 2008, and 30.3\% between 2008 and 2012. While taking into consideration that we do not have the same duration between these periods. The probabilities of being very unfavorable or unfavorable for more redistribution (or more precisely favorable to the idea we need larger income differences as incentives for individual effort) are also different 
to those of 2008-2012. There is $18 \%$ less chance that an individual takes this position in 2008 compared to 2000, this percentage is $35,5 \%$ in 2012 compared to 2008 .

\section{Heterogeneous treatment effects}

In this extension we want to shed light on which groups have the most forceful response to the revolution. We test this differential effect on each one of the variables we tested. We found that the heterogeneous effect exists only over the financial situation groups, over the health situation groups, and over the degree of interest in politics groups. We start by testing the effect of time proper to Egypt (effect of revolution) on the support for redistribution over the financial situation groups. In table 21 we estimate the equation (3), where we interact the financial situation index with wave change. The analysis indicates, relative to the lowest financial situation group, that the effect of the revolution becomes smaller and smaller each time the financial situation is better.

To obtain the marginal effects concerning every financial situation group, we re-estimate the equation (1) separately for each group. Like we find in table 22, the heterogeneity of the effect goes in the direction of having a weaker positive effect for the higher financial situation group compared to the middle and the lower financial situations groups. The probability to be very favorable increasing after the revolution by 0.349 (marginal effects) for the low financial situation, by 0.301 for the average financial situation, and by 0.237 for the high financial situation. In turn, suggesting that the revolution increased the gap in demand for redistribution across wealth groups. One potential explanation for these heterogeneous effects could be that the revolution, was more concerning the low and medium category than the high category, like the spreading of ideas about social inequality.

In column 2 in table 21, we include the interaction between the number of the wave and the health situation. We conclude that the effect of the revolution differs significantly between individuals having good health and those having bad health: the positive effect of the revolution on demand for redistribution affected much more the people in poor health than the people in good health. Insofar as the state of health is one of the components of well-being as the financial situation, this result joined the previous one. This variable also reflects a part of the risk exposure: A lousy health exposes the individual's future to more risk compared to healthy ones.

In table 22, we include in column 1 the interaction between the number of wage (date of survey) and the categorical variable indicating the degree of interest in politics the individual 
gives. We found that the individuals who are very interested in politics were impacted positively by the revolution on those preferences for redistribution much more than individuals not interested at all in politics. This result shows that a part of the positive revolution effect of the revolution lies in the considerable change in the new political scene after the revolution that we explained in Section 2. We add in column 2 in the same table the interaction between the number of wave and effect and the individual age group. The youngest category seems to be the less group infected by the positive effect of the revolution on demand for redistribution, even if these coefficients are weakly significant.

After all these regressions, we can conclude that the 25 January revolution had an enormous effect on the demand for redistribution in Egypt. Our results concerning the interactions and what changed as a result of the revolution can help us explain this effect. The fact that the most unfortunate individuals were more affected than the richest prove that the new political offer was relying effectively on what touches more this group, namely for example inequality and social justice. The fact that the most interested individuals in politics were the most affected by this positive effect prove that the improvement of the freedom situation was an essential part of this positive effect: the most interested in politics benefited the most from this situation. Admittedly, these arguments cannot in themselves explain the overall effect, we still have a substantial part not explained that we do not pretend to be able to explain it entirely.

\section{Discussion}

We showed in Section 5 how we managed to isolate the effect of the political and informational freedom change, and then emphasized the substantial positive impact of these latter on the preferences for redistribution. The question that comes naturally is why the revolution had this strong effect on people's preferences concerning redistribution? How can a change in the political sphere along with an improvement of the freedom lead to enhance the support for redistribution? By what channels (mediators) could this effect pass? Unfortunately, the limited set of information in our database limits our ability to dig further to explain this effect, but in the other side, many elements the literature allows us to set some assumptions in this direction.

Since the revolution is considered as a "shock" (we mean by a shock a major event that happens all of a sudden), we look first at the literature dealing with the effects of shocks. In this literature the shocks (we mean by a shock a major event that happens all of a sudden) that were explored in the context of the demand for redistribution are in the vast majority economic shocks, especially the recent economic crises that have hit the European countries and 
the United states (Margalit, 2013; Olivera, 2014; Kroeger, 2014). ${ }^{5}$ In our case, this shock does not seem to have economic consequences: Section 3 has established that the basic economic indicators up to the eve of the revolution were not deteriorating, and that after revolution based on data that we study, the composition of individuals concerning the economic situation was the same. It is also shown in the regressions that the perception of the economic situation did not explain this change. Once the possibility that the revolution is an economic shock has been ruled out, it remains to be known what kind of shock is more like the revolution. We will use all that we have discussed in Section 3 about the Egyptian revolution to propose our own hypothesis on the subject.

As explained in Section 3, in first individual freedoms have undergone a major change mainly regarding freedom of information through the evolution of the role of the Internet and the high flow of news that has been exposed to the Egyptians. The other change was at the level of political life, Egyptians experienced the emergence of a new political class from elections deemed free and with a very high participation rate. Schläpfer, Schmitt, and Roschewitz (2008) showed how the preferences of citizens could be influenced by political institutions and especially by party programs, Ford (2016) explains in turn how moral narratives adopted by political and media elites can manipulate the individual perceptions about welfare. We then have a people after the revolution that is very interested in politics, which is facing a new political discourse inspired by the revolution whose term of social justice was one of the central themes, and which has new sources of information. All of this leads us to believe that the shock that the revolution caused was an "information" shock that largely targets the economic reality of the country.

In fact, Individual perceptions of the personal or general economic situation may be subject to many misconceptions. Hauser and Norton (2017) and Kuziemko, Norton, Saez, and Stantcheva (2015) showed that it exists a substantial difference between the actual levels of inequality and the person's (mis)perception of those levels. The individual's perceptions of their equality of opportunity or the future income can also be different from the objective measures (Alesina and La Ferrara (2005)). Fulfilling this gaps may lead to a correction of the demand for redistribution attitude: Cruces, Perez-Truglia, and Tetaz (2013) and Karadja, Mollerstrom, and Seim (2017) provide evidence on the significant biases in individuals' evaluations of their relative position in the income distribution and showed how individuals modify their preferences as soon as they have the right information. Kuziemko et al. (2015) found a significant but weak effect on the individuals' preferences when they learn the actual level of inequality. Cruces et al. (2013) found that this perception is a statistical inference problem, a reference

\footnotetext{
${ }^{5}$ We can find Dahlberg et al. (2012) who studied the effect of the large immigration on the support for redistribution considered then as a "social" shock.
} 
group bias. Diermeier, Goecke, Niehues, and Thomas (2017) showed that one of the misperceptions of the level of inequality sources was the media coverage on the perceptions of the level of inequality not only between Egyptians themselves but compared to the rest of the world. ${ }^{6}$ In Egypt, it can be supposed that the shock of information allowed the people to have more correct information about their income position and the level of inequality. A change of the group inference or a different media coverage can be the source of these perceptions changes. The unique prove in our study is - as we showed in the heterogeneous effect section - that the people most interested in politics were more concerned about the positive effect of the revolution on people's preferences, which means the new political environment is a part of the explanation.

Other kinds of information different than those cited in the literature may also have an effect on individuals' preferences for redistribution. One element that is thought to be interesting and which is induced by the new political discourse is the development of the political culture on the question of the distributive role of the state. In developed countries where most of the literature on the demand for redistribution has been made, it is implicitly assumed that individuals are aware of all the options available to them, including the option of reducing inequalities through a redistribution of the state from the rich to the poor. Difficult access to information and a repressive political system for decades, as was the case for Egypt, and for many other countries in the Middle East, may have the consequence of plunging the country into a position of ignorance, even of the most fundamental rights. This situation can impose incomplete preferences, or a bounded rationality, in the sense that the set of choices is more limited compared to a more democratic society. ${ }^{7}$ The revolution then allowed people to open their eyes to new possibilities such as improving the economic situation through less inequality.

\section{Conclusion}

This document addresses two important issues: the determinants of the support for redistribution in Egypt, and the effect of the Egyptian revolution occurred in 2011 on this support. In the first part of the results Section, although many of the factors have the expected effects on demand for redistribution, including the financial situation, some factors stand out. Being richer, more educated, young, in a bad health, in left decrease the individual demand for redistribution. Attend religious activities enhance the individual support for redistribution contrary to the classical finding in the literature. An another surprisingly result is the negative effect of

\footnotetext{
${ }^{6} \mathrm{~A}$ big shift in the "reference point" as has been explained by Charité, Fisman, and Kuziemko (2015).

${ }^{7}$ Hong, Ding, and Yao (2015) showed how unfounded beliefs or the erroneous processing of information could generate the "irrationality" of individual social welfare preferences
} 
having an altruistic attitude. Our explanations for these results put the accent on the specific cultural and social structure of the Egyptian society specially and the Arab one more generally. The strong presence of religion and the sustenance of alternative forms of social transfers seem to weigh on the formation of individual attitudes.

The second part of the results deals with the effect of time between 2008 and 2012. Since the only major event happened between these years was the Egyptian revolution, we suppose that the effect of time controlled by the appropriate factors is the effect of the revolution. The Egyptian revolution is not only the event itself but all the consequences that followed. This study provides compelling evidence of the substantial positive impact of the revolution on individuals' preferences for redistribution. It has been shown that none of the factors considered as determinants of redistribution preference can explain this time effect. A diff-in-diff analysis also showed that this effect persists even if we control it with the effect of time proper to the countries we take into account (Jordan, Morocco and Turkey). We also showed that even if a positive trend existed between 2000 and 2008, the marginal effects are much smaller than the ones we obtained for the revolution period. This positive effect was mostly homogeneous between the different individuals, except for those who differ in their financial situation and their degree of interest in politics : Individuals who feel financially challenged, and who are very interested in politics have seen their support for redistribution increase more sharply compared respectively to those in a more comfortable financial situation and the individuals who are not interested at all in politics.

The limits of this study are numerous. The first one is the difficulty of analyzing a rather complex and multidimensional phenomenon that a revolution. We do not pretend to be able to explain everything, we are just interested in a part that we consider to be important in the process. The second is the control group with which Egypt is compared. Although there are significant similarities between the countries chosen at the political and economic levels, the trends over time were not the same, and several non-measurable differences can be hidden playing a role in the evolution of preferences. The third limitation concerns the limited number of variables available to explain the preference of the individual. Further information on the individuals such as their entourage for example, or their attitudes as well as their perceptions of social inequalities and mobility will have been very useful. The fourth limitation is the lack of documentation that can help us build the foundation of our assumptions presented about the mechanisms generating the redistribution attitude evolution as a result of the political and informational change.

Our work opens a big door for studying the preferences for redistributions intensely for the 
Arab countries: shedding light on the specificities of this environment, especially on all what can be related to the social transfer and religion. In this paper, we limited our analysis on the essential of this topic, but much more can be done. Our study also draws the attention to the importance of the level of freedom and the political institutions on the formation of individuals support for redistribution. This theme is gaining in importance since the deteriorating of the state of democracy in the world as mentioned in the report named "Democracy in crisis" by Freedom House (2018). The factor of freedom - in the broader sense of the term - is until now very little exploited concerning its effect on the individual's preferences for the redistribution.

\section{References}

Facundo Alvaredo, Lucas Chancel, Thomas Piketty, Emmanuel Saez, and Gabriel Zucman. World inequality report 2018. Belknap Press of Harvard University Press, 2018.

Christina Fong. Social preferences, self-interest, and the demand for redistribution. Journal of Public economics, 82(2):225-246, 2001.

Giacomo Corneo and Hans Peter Grüner. Individual preferences for political redistribution. Journal of public Economics, 83(1):83-107, 2002.

Alberto F Alesina and Paola Giuliano. Preferences for redistribution. Technical report, National Bureau of Economic Research, 2009.

Daron Acemoglu, Suresh Naidu, Pascual Restrepo, and James A Robinson. Democracy, redistribution, and inequality. In Handbook of income distribution, volume 2, pages 1885-1966. Elsevier, 2015.

Felix Schläpfer, Marcel Schmitt, and Anna Roschewitz. Competitive politics, simplified heuristics, and preferences for public goods. Ecological economics, 65(3):574-589, 2008.

Will Kymlicka. Dworkin on freedom and culture. Wiley Online Library, 2004.

Javier Olivera. Preferences for redistribution after the economic crisis. Economics and Business Letters, 3(3):137-145, 2014.

Philipp Kroeger. Demand for redistribution in the wake of the economic crisis. Economics and Business Letters, 3(3):156-165, 2014.

Yotam Margalit. Explaining social policy preferences: Evidence from the great recession. American Political Science Review, 107(1):80-103, 2013. 
Matz Dahlberg, Karin Edmark, and Heléne Lundqvist. Ethnic diversity and preferences for redistribution. Journal of Political Economy, 120(1):41-76, 2012.

Eric Brunner, Stephen L Ross, and Ebonya Washington. Economics and policy preferences: causal evidence of the impact of economic conditions on support for redistribution and other ballot proposals. Review of Economics and Statistics, 93(3):888-906, 2011.

Freedom House. Freedom in the world 2018. democracy in crisis. Freedom House, 2018.

Ibrahim Elbadawi and Samir Makdisi. Democracy in the Arab world: explaining the deficit. Routledge, 2010.

Andrea Teti, Pamela Abbott, and Francesco Cavatorta. The Arab Uprisings in Egypt, Jordan and Tunisia: Social, Political and Economic Transformations. Springer, 2017.

Massoud Karshenas, Valentine M Moghadam, and Randa Alami. Social policy after the arab spring: States and social rights in the mena region. World Development, 64:726-739, 2014.

Azmi Bishara. Being arab in nowdays. 2009.

Jason Brownlee, Tarek E Masoud, and Andrew Reynolds. The Arab Spring: Pathways of Repression and Reform. Oxford University Press, 2015.

The World Bank. Gdp growth egypt between 2001 and 2016. https://data.worldbank. org/indicator/NY . GDP . MKTP. KD . ZG?end=2016\&locations=EG\&start=2001, 2018. [Online; accessed 23-July-2018].

Prof Abdou, Doaa Salman, and Zeinab Zaazou. The egyptian revolution and post socioeconomic impact. 2013.

Matthew Costello, J Craig Jenkins, and Hassan Aly. Bread, justice, or opportunity? the determinants of the arab awakening protests. World Development, 67:90-100, 2015.

Amnesty international. Egypt: Abuses under state of emergency. http://archive.is/91ixu\# selection-391.0-391.38, 2011. [Online; accessed 23-July-2018].

Noha El-Mikawy. The building of consensus in Egypt's transition process. American Univ in Cairo Press, 1999.

Dalia Othman. State of emergency ends, military council says will not renew. http://www. egyptindependent.com/military-council-says-no-extension-emergency-law/, 2012. [Online; accessed 23-July-2018]. 
Freedom house. Freedom situation in egypt in 2008. https://freedomhouse.org/report/ freedom-world/2008/egypt, 2008.

Freedom house. Freedom situation in egypt in 2009. https://freedomhouse.org/report/ freedom-world/2009/egypt, 2009.

Freedom house. Freedom situation in egypt in 2010. https://freedomhouse.org/report/ freedom-world/2010/egypt, 2010.

Hamid Dabashi. The Arab Spring: the end of postcolonialism. Zed Books Ltd., 2012.

Shibley Telhami. The world through Arab eyes: Arab public opinion and the reshaping of the Middle East. Basic Books (AZ), 2013.

Ian Vasquez and Tanja Porcnik. The Human Freedom Index 2016: A Global Measurement of Personal, Civil, and Economic Freedom. Cato Institute, 2016.

Racha Mourtada and Fadi Salem. Civil movements: The impact of facebook and twitter. Arab Social Media Report, 1(2):1-30, 2011.

Gadi Wolfsfeld, Elad Segev, and Tamir Sheafer. Social media and the arab spring: Politics comes first. The International Journal of Press/Politics, 18(2):115-137, 2013.

Gilad Lotan, Erhardt Graeff, Mike Ananny, Devin Gaffney, Ian Pearce, et al. The arab spring| the revolutions were tweeted: Information flows during the 2011 tunisian and egyptian revolutions. International journal of communication, 5:31, 2011.

Ekaterina Stepanova. The role of information communication technologies in the "arab spring". Ponars Eurasia, 15:1-6, 2011.

Philip N Howard, Aiden Duffy, Deen Freelon, Muzammil M Hussain, Will Mari, and Marwa Maziad. Opening closed regimes: what was the role of social media during the arab spring? 2011.

M Murthi and ER Tiongson. Attitudes to equality: the 'socialist legacy'revisited policy. World Bank Research Working Paper, 4529, 2008.

Moses Shayo. A model of social identity with an application to political economy: Nation, class, and redistribution. American Political Science Review, 103(2):147-174, 2009.

Esteban F Klor and Moses Shayo. Social identity and preferences over redistribution. Journal of Public Economics, 94(3):269-278, 2010. 
Alberto Alesina and Eliana La Ferrara. Preferences for redistribution in the land of opportunities. Journal of public Economics, 89(5):897-931, 2005.

Marius R Busemeyer. Education funding and individual preferences for redistribution. European Sociological Review, 29(6):1122-1133, 2013.

Frank Neher. Preferences for redistribution across the world. School of Business 6 Economics Discussion Paper: Economics, (2012/2), 2011.

Elvire Guillaud. Preferences for redistribution: an empirical analysis over 33 countries. The Journal of Economic Inequality, 11(1):57-78, 2013.

Javier Olivera. Preferences for redistribution in europe. IZA Journal of European Labor Studies, 4(1):14, 2015.

Maria Grazia Pittau, Alessio Farcomeni, and Roberto Zelli. Has the attitude of us citizens towards redistribution changed over time? Economic Modelling, 52:714-724, 2016.

Serena Fatica. Preferences for redistribution, the size of government and the tax system. 2011.

Erzo FP Luttmer and Monica Singhal. Culture, context, and the taste for redistribution. American Economic Journal: Economic Policy, 3(1):157-179, 2011.

Ilja Neustadt. Do religious beliefs explain preferences for income redistribution? experimental evidence. CESifo Economic Studies, 57(4):623-652, 2011.

John H Beck. An experimental test of preferences for the distribution of income and individual risk aversion. Eastern Economic Journal, 20(2):131-145, 1994.

Philipp Rehm. Risks and redistribution: An individual-level analysis. Comparative political studies, 42(7):855-881, 2009.

Thomas Piketty. Social mobility and redistributive politics. The Quarterly journal of economics, 110(3):551-584, 1995.

Martin Ravallion and Michael Lokshin. Who wants to redistribute?: The tunnel effect in 1990s russia. Journal of public Economics, 76(1):87-104, 2000.

Robert Ford. Who should we help? an experimental test of discrimination in the british welfare state. Political Studies, 64(3):630-650, 2016.

Oliver P Hauser and Michael I Norton. (mis) perceptions of inequality. Current opinion in psychology, 18:21-25, 2017. 
Ilyana Kuziemko, Michael I Norton, Emmanuel Saez, and Stefanie Stantcheva. How elastic are preferences for redistribution? evidence from randomized survey experiments. The American Economic Review, 105(4):1478-1508, 2015.

Guillermo Cruces, Ricardo Perez-Truglia, and Martin Tetaz. Biased perceptions of income distribution and preferences for redistribution: Evidence from a survey experiment. Journal of Public Economics, 98:100-112, 2013.

Mounir Karadja, Johanna Mollerstrom, and David Seim. Richer (and holier) than thou? the effect of relative income improvements on demand for redistribution. Review of Economics and Statistics, 2017.

Matthias Diermeier, Henry Goecke, Judith Niehues, and Tobias Thomas. Impact of inequalityrelated media coverage on the concerns of the citzens. Number 258. DICE Discussion Paper, 2017.

Jimmy Charité, Raymond Fisman, and Ilyana Kuziemko. Reference points and redistributive preferences: Experimental evidence. Technical report, National Bureau of Economic Research, 2015.

Hao Hong, Jianfeng Ding, and Yang Yao. Individual social welfare preferences: An experimental study. Journal of Behavioral and Experimental Economics, 57:89-97, 2015. 


\section{Appendix 1: Description of variables}

The following is a list of the variables we use and their sources, followed by summary statistics. Unless otherwise stated, the source of a variable is author's calculation on WVS data.

- Pref for redis: Categorical variable varying on a 5 point scale from $1=$ against distribution to $5=$ in favor for redistribution. Original WVS survey question (ppr1) : " I'd like you to tell me your views on various issues. How would you place your views on this scale? 1 means you agree completely with the statement on the left (Incomes should be made more equal) ; 10 means you agree completely with the statement on the right (We need larger income differences as incentives for individual effort); and if your views fall somewhere in between, you can choose any number in between". Our variable is rescaled (11-ppr1), i.e it is increasing in individual support for redistribution, and then regrouped in 5 groups $(P p r)$.

- Age: Categorical variable presenting 4 categories of age equal to 1 if the age of the respondent is between 18 and 25, 2 if the age of the respondent is between 26 and 39,3 if the age of the respondent is between 49 and 59 , and 4 if the age of the respondent is above 59 .

- Woman: dummy equal to 1 if the respondent is female.

- Education: Categorical variable presenting 4 categories of educational level equal to 1 if the respondent is illiterate, 2 if the respondent has a low level of education (less than secondary school), 3 if the respondent has a complete secondary school, 4 if the respondent had a university formation.

- Children: dummy equal to 1 if the respondent has children

- badhealth: dummy equal to 1 if the respondent is in a bad or very bad health situation and equal to 0 otherwise.

- Financial sit: Categorical variable presenting 5 categories of financial situation equal to 1 if the respondent is very dissatisfied with his financial situation, and equal to 5 if the respondent is very satisfied with his financial situation.

- After Revolution: dummy equal to 1 if the respondent is living in 2008 and to 0 if the respondent is living in 2012.

- Trust: dummy equal to 1 if the respondent thinks that most people can be trusted and equal to 0 if the respondent thinks that we can not be too careful. This is a proxy for the reciprocity attitude. 
- Politic ideo: Categorical variable presenting 3 categories of the ideological position between left and right equal to 1 if the respondent is considering himself having a left ideological position, 2 if the respondent is considering himself in the middle (between these 2 positions), and 3 if the respondent is considering himself having a right ideological position. (The variable is coded in the database in the scale of 10: 1 for left and 10 for right).

- Religious: Categorical variable presenting 2 categories of how often the individual attend religious services, it is equal to 1 if the respondent attends religious services once a week or more, and 0 if otherwise.

- Risk attitude: Categorical variable presenting 3 categories of how important it is to take risks. It is a proxy for the risk attitude. It is taking the value of 1 if the respondent likes to take risks instead, the value of 3 if the respondent doesn't like to take risks instead, and the value of 2 if the respondent is in between these 2 positions.

- Imp of Help: Categorical variable presenting 3 categories on the subject of how it is important to help the people nearby. It is considering as a proxy for the altruism attitude. This variable is equal to 1 if the respondent is considering himself as an altruistic, 3 if it is not, and 2 if he is between these 2 positions.

- childaltruisme: dummy equal to 1 if the respondent think that the unselfishness is an important quality child. It can also be considered as a proxy for the altruism attitude.

- Interest in Poli: Categorical variable presenting 4 categories on the subject of how the respondent is interesting in politics, equal to 1 the respondent is not at all interested in politics, equal to 2 if the respondent is not very interested in politics, to 3 if the respondent is somewhat interested in politics, to 4 if the respondent is very interested in politics.

- Role of effort: Categorical variable presenting 3 categories on the subject of how much freedom of choice and control the respondent thinks he has in this life. It can be considered as a proxy for the fairness beliefs about the effort and chance at the personal level. This variable is equal to 1 if the respondent thinks that he has no liberty and choice in his life (so thinks that the effort does not has an effect), 3 he thinks that he has a control in his life (so thinks that he believes in effort more than luck), and 2 if he is between these 2 positions.

- Group of variables A: age, gender, education level, having children, financial situation, being in a bad health, political ideology, attend religious services, trust others, altruism attitude, being interested in politics, the perception of the role of effort in one's own life. 
- Group of variables B: age, gender, education level, having children and financial situation.

- Group of variables C: Age, Woman, Children, Finan sit, badhealth, trust people, childaltruisme, Interest in Poli and Role of effort.. 


\section{Appendix 2 : Informations concerning the Freedom, political and eco- nomic situations in Egypt}

Table 3: Some components of freedom situation in Egypt between 2008 and 2012

\begin{tabular}{lllll}
\hline Freedom in Egypt & 2008 & 2009 & 2011 & 2012 \\
\hline 1. Association, Assembly \& Civil Society & $\mathbf{3 . 6}$ & $\mathbf{3 . 6}$ & $\mathbf{5 . 8}$ & $\mathbf{5 . 8}$ \\
i. Freedom of Association & 2.5 & 2.5 & 5.0 & 5.0 \\
ii. Freedom of Assembly and Demonstration & 2.5 & 2.5 & 7.5 & 7.5 \\
iii. Autonomy of Organisations & 4.4 & 4.4 & 4.2 & 4.2 \\
iv. Freedom to Establish Organisations & 5.0 & 5.0 & 6.7 & 6.7 \\
& & & & \\
2. Expression \& Information & $\mathbf{5 . 6}$ & $\mathbf{5 . 6}$ & $\mathbf{6 . 3}$ & $\mathbf{6 . 3}$ \\
i. Press kilings & 10.0 & 10.0 & 7.5 & 8.8 \\
ii. Laws and regulation that influence media content & 3.0 & 3.0 & 3.3 & 2.7 \\
iii. Political pressures and controls on media content & 4.8 & 4.8 & 4.5 & 4.0 \\
iv. Freedom of access to Foreign information & 6.7 & 6.7 & 8.8 & 4.0 \\
v. State control over internet access & 3.3 & 3.3 & 7.5 & 7.5 \\
\hline Sour : Th Hen
\end{tabular}

Source : The Human Freedom Index (HFI) Egypt (2016 report).

Table 4: Some economic indicators for Egypt between 2004 and 2012

\begin{tabular}{lccccccccc}
\hline Indicators & 2004 & 2005 & 2006 & 2007 & 2008 & 2009 & 2010 & 2011 & 2012 \\
\hline GDP Growth (\%) & 4.09 & 4.47 & 6.85 & 7.09 & 7.15 & 4.67 & 5.14 & 1.78 & 2.16 \\
Gini indicator & 31.9 & - & - & - & 31.5 & - & 31.5 & - & 31.5 \\
HDI & - & 0.64 & 0.65 & 0.65 & 0.66 & 0.67 & 0.68 & 0.68 & 0.68 \\
\hline
\end{tabular}

Table 5: Voter turnout for some elections in Egypt between 2005 and 2012

\begin{tabular}{lcccc}
\hline Elections & 2005 & 2010 & 2011 & 2012 \\
\hline Presidential & $22.95 \%$ & - & - & $51.85 \%$ \\
Parlimentary & $28.13 \%$ & $27.47 \%$ & $62.04 \%$ & - \\
\hline
\end{tabular}


Table 6: Summary of the 2011 election for People's Assembly of Egypt

\begin{tabular}{|c|c|c|c|c|c|}
\hline Party & $\begin{array}{l}\text { Component } \\
\text { Parties }\end{array}$ & $\begin{array}{l}\text { Date of } \\
\text { fondation }\end{array}$ & Vote $\%$ & Total seats & $\%$ Seats \\
\hline \multirow[t]{8}{*}{$\begin{array}{l}\text { Democratic Alliance } \\
\text { for Egypt }\end{array}$} & $\begin{array}{l}\text { Freedom \& Justice } \\
\text { Party: } 213\end{array}$ & 2011 & 37.5 & 235 & 46.26 \\
\hline & Dignity Party: 6 & 1996 & & & \\
\hline & $\begin{array}{l}\text { Ghad,El-Thawra } \\
\text { Party: } 2\end{array}$ & 2011 & & & \\
\hline & Civilization,Party: 2 & 2011 & & & \\
\hline & $\begin{array}{l}\text { Islamic,Labour } \\
\text { Party: } 1\end{array}$ & 1998 & & & \\
\hline & $\begin{array}{l}\text { Egyptian Arab } \\
\text { Socialist Party: } 1\end{array}$ & 1977 & & & \\
\hline & $\begin{array}{l}\text { Egyptian } \\
\text { Reform Party: } 1\end{array}$ & 2011 & & & \\
\hline & $\begin{array}{l}\text { Affiliated } \\
\text { Independents } 9\end{array}$ & & & & \\
\hline \multirow[t]{3}{*}{ Islamist Bloc } & $\begin{array}{l}\text { Al-Nour } \\
\text { Party: } 107\end{array}$ & 2011 & 27.8 & 121 & 23.82 \\
\hline & $\begin{array}{l}\text { Building\& } \\
\text { Development Party: } 13\end{array}$ & 2011 & & & \\
\hline & Authenticity Party: 3 & 2011 & & & \\
\hline New Wafd Party & & 1978 & 9.2 & 41 & 8.07 \\
\hline \multirow[t]{3}{*}{ Egyptian Bloc } & $\begin{array}{l}\text { Social Democratic } \\
\text { Party: } 16\end{array}$ & 2011 & 8.9 & 35 & 6.89 \\
\hline & $\begin{array}{l}\text { Free Egyptians } \\
\text { Party: } 15\end{array}$ & 2011 & & & \\
\hline & $\begin{array}{l}\text { Progressive } \\
\text { Unionist Party: } 4\end{array}$ & 1977 & & & \\
\hline Al-Wasat Party & & 1996 & 3.7 & 10 & 1.97 \\
\hline \multirow[t]{3}{*}{$\begin{array}{l}\text { The Revolution } \\
\text { Continues Alliance }\end{array}$} & $\begin{array}{l}\text { Socialist Popular } \\
\text { Alliance Party: } 7\end{array}$ & 2011 & 2.8 & 9 & 1.77 \\
\hline & Freedom Egypt Party: 1 & 2011 & & & \\
\hline & $\begin{array}{l}\text { Equality \& } \\
\text { Development Party: } 1\end{array}$ & 2011 & & & \\
\hline $\begin{array}{l}\text { Reform and Development } \\
\text { Party }\end{array}$ & & 2009 & 2.2 & 9 & 1.77 \\
\hline Freedom Party & & 2011 & 1.9 & 4 & 0.79 \\
\hline National Party of Egypt & & 2011 & 1.6 & 5 & 0.98 \\
\hline Egyptian Citizen Party & & 2011 & 0.9 & 4 & 0.79 \\
\hline Union Party & & 2011 & 0.5 & 2 & 0.39 \\
\hline Conservative Party & & 2006 & 1.0 & 1 & 0.2 \\
\hline Democratic Peace Party & & 2005 & 0.9 & 1 & 0.2 \\
\hline Justice Party & & 2011 & 0.7 & 1 & 0.2 \\
\hline Arab Egyptian Unity Party & & 2011 & 0.6 & 1 & 0.2 \\
\hline Nasserist Party & & 1992 & 0.6 & 1 & 0.2 \\
\hline Independents & & - & - & 21 & 0.2 \\
\hline Total elected & & & & 489 & 4.13 \\
\hline SCAF appointees & & & & 10 & \\
\hline Total & & & & 508 & \\
\hline
\end{tabular}




\section{Appendix 3: Summary statistics}

Table 7: Availability of Data by wave for some countries

\begin{tabular}{lcc}
\hline Topic & Wave 5 & Wave 6 \\
\hline Algeria & No & Yes \\
Egypt & Yes & Yes \\
Iraq & Yes & Yes \\
Jordan & Yes & Yes \\
Kuwait & No & Yes \\
Lebanon & No & Yes \\
Libya & No & Yes \\
Morocco & Yes & Yes \\
Palestine & No & Yes \\
Qatar & No & Yes \\
Tunisia & No & Yes \\
Turkey & Yes & Yes \\
Yemen & No & Yes \\
\hline
\end{tabular}


Table 8: Summary statistics : Jordan

\begin{tabular}{|c|c|c|c|c|c|c|c|}
\hline & \multicolumn{7}{|c|}{ Jordan } \\
\hline & \multicolumn{3}{|c|}{$\begin{array}{c}\text { Before Revolution } \\
(01-05-2007-30-06-2007)\end{array}$} & \multicolumn{3}{|c|}{$\begin{array}{c}\text { After Revolution } \\
(19-02-2014-01-03-2014)\end{array}$} & \multirow[b]{2}{*}{$\operatorname{Max}$} \\
\hline & Mean & $\mathrm{Sd}$ & $\mathrm{N}$ & Mean & $\mathrm{Sd}$ & $\mathrm{N}$ & \\
\hline Pref for redistribution & 2.27 & 1.62 & 1101 & 2.19 & 1.15 & 1127 & 5 \\
\hline \multicolumn{8}{|l|}{ Individual characteristics } \\
\hline Age & 2.28 & 0.9 & 1159 & 2.44 & 0.92 & 1130 & 4 \\
\hline Woman & 0.51 & 0.5 & 1159 & 0.51 & 0.49 & 1130 & 1 \\
\hline Education level & 2.37 & 1.07 & 1067 & 2.16 & 1.12 & 1120 & 4 \\
\hline Having Children & 0.68 & 0.46 & 1159 & 0.76 & 0.42 & 1128 & 1 \\
\hline \multicolumn{8}{|l|}{ Current Welfare } \\
\hline Financial situation & 3.44 & 1.3 & 1149 & 2.93 & 1.15 & 1130 & 5 \\
\hline \multicolumn{8}{|l|}{ Attitudinal variables } \\
\hline Ideological position & 2.06 & 0.845 & 318 & - & - & - & 3 \\
\hline Attend Religious activities & - & - & - & 0.52 & 0.49 & 1130 & 1 \\
\hline Aversion to risque & 2.41 & 0.63 & 1122 & 1.94 & 0.87 & 1125 & 3 \\
\hline Social trust & 3.44 & 1.57 & 1141 & 3.02 & 1.48 & 1125 & 5 \\
\hline Importance of helping & 2.86 & 0.35 & 1132 & 2.78 & 0.46 & 1125 & 3 \\
\hline Altruism to Children & 0.55 & 0.49 & 1159 & 0.36 & 0.48 & 1130 & 1 \\
\hline Having control (Effort role) & 2.61 & 0.68 & 1148 & 2.58 & 0.64 & 1130 & 3 \\
\hline Being interested in politics & 2.18 & 0.98 & 1151 & 2.14 & 0.96 & 1130 & 4 \\
\hline
\end{tabular}


Table 9: Summary statistics : Turkey

\begin{tabular}{|c|c|c|c|c|c|c|c|}
\hline & \multicolumn{7}{|c|}{ Turkey } \\
\hline & \multicolumn{3}{|c|}{$\begin{array}{c}\text { Before Revolution } \\
(28-01-2007-05-03-2007)\end{array}$} & \multicolumn{3}{|c|}{$\begin{array}{c}\text { After Revolution } \\
(30-06-2012-25-08-2012)\end{array}$} & \multirow[b]{2}{*}{$\operatorname{Max}$} \\
\hline & Mean & $\mathrm{Sd}$ & $\mathrm{N}$ & Mean & $\mathrm{Sd}$ & $\mathrm{N}$ & \\
\hline Pref for redistribution & 3.27 & 1.46 & 1267 & 3.4 & 1.29 & 1523 & 5 \\
\hline \multicolumn{8}{|l|}{ Individual characteristics } \\
\hline Age & 2.26 & 0.88 & 1293 & 2.33 & 0.89 & 1559 & 4 \\
\hline Woman & 0.49 & 0.5 & 1293 & 0.517 & 0.49 & 1559 & 1 \\
\hline Education level & 2.11 & 1.13 & 1186 & 2.24 & 1.14 & 1557 & 4 \\
\hline Having Children & 0.66 & 0.47 & 1292 & 0.64 & 0.47 & 1559 & 1 \\
\hline \multicolumn{8}{|l|}{ Current Welfare } \\
\hline Financial situation & 3.25 & 1.04 & 1288 & 3.38 & 1.01 & 1539 & 5 \\
\hline \multicolumn{8}{|l|}{ Attitudinal variables } \\
\hline Ideological position & 2.18 & 0.80 & 1293 & 2.24 & 0.78 & 1411 & 3 \\
\hline Attend Religious activities & 0.34 & 0.47 & 1100 & 0.3 & 0.46 & 1536 & 1 \\
\hline Aversion to risque & 1.85 & 0.81 & 1286 & 2.04 & 0.78 & 1527 & 3 \\
\hline Social trust & 2.62 & 1.25 & 1251 & 3.08 & 1.21 & 1543 & 5 \\
\hline Importance of helping & 2.71 & 0.51 & 1264 & - & - & - & 3 \\
\hline Altruism to Children & 0.31 & 0.46 & 1293 & 0.28 & 0.45 & 1559 & 1 \\
\hline Having control (Effort role) & 2.56 & 0.71 & 1270 & 2.62 & 0.87 & 1540 & 3 \\
\hline Being interested in politics & 2.15 & 0.97 & 1290 & 2.44 & 0.63 & 1545 & 4 \\
\hline
\end{tabular}


Table 10: Summary statistics : Morroco

\begin{tabular}{|c|c|c|c|c|c|c|c|}
\hline & \multicolumn{7}{|c|}{ Morroco } \\
\hline & \multicolumn{3}{|c|}{$\begin{array}{c}\text { Before Revolution } \\
(15-09-2007-07-10-2007)\end{array}$} & \multicolumn{3}{|c|}{$\begin{array}{c}\text { After Revolution } \\
(25-05-2011-18-06-2011)\end{array}$} & \multirow[b]{2}{*}{ Max } \\
\hline & Mean & $\mathrm{Sd}$ & $\mathrm{N}$ & Mean & $\mathrm{Sd}$ & $\mathrm{N}$ & \\
\hline Pref for redistribution & 3.06 & 1.36 & 1157 & 3.18 & 1.43 & 842 & 5 \\
\hline \multicolumn{8}{|l|}{ Individual characteristics } \\
\hline Age & 2.30 & 0.87 & 1178 & 2.30 & 0.88 & 1182 & 4 \\
\hline Woman & 0.50 & 0.50 & 1178 & 0.50 & 0.50 & 1882 & 1 \\
\hline Education level & 2.14 & 1.07 & 482 & 1.48 & 0.88 & 1882 & 4 \\
\hline Having Children & 0.69 & 0.45 & 987 & 0.59 & 0.49 & 1173 & 1 \\
\hline \multicolumn{8}{|l|}{ Current Welfare } \\
\hline Financial situation & 2.77 & 0.96 & 1177 & 3.07 & 1.12 & 1171 & 5 \\
\hline \multicolumn{8}{|l|}{ Attitudinal variables } \\
\hline Ideological position & 2.14 & 0.61 & 494 & 2.06 & 0.76 & 206 & 3 \\
\hline Attend Religious activies & 0.91 & 0.28 & 1168 & - & - & - & 1 \\
\hline Aversion to risque & 1.91 & 0.81 & 1125 & 1.84 & 0.76 & 1022 & 3 \\
\hline Social trust & 2.21 & 1.17 & 1152 & 2.67 & 1.22 & 1096 & 5 \\
\hline Importance of helping & 2.59 & 0.56 & 1153 & 2.56 & 0.58 & 1084 & 3 \\
\hline Altruism to Children & 0.36 & 0.48 & 1178 & 0.25 & 0.43 & 1182 & 1 \\
\hline Having control (Effort role) & 1.97 & 0.82 & 1163 & 1.63 & 0.71 & 1038 & 3 \\
\hline Being interested in politics & 2.05 & 0.97 & 1097 & 2.22 & 0.81 & 1142 & 4 \\
\hline
\end{tabular}




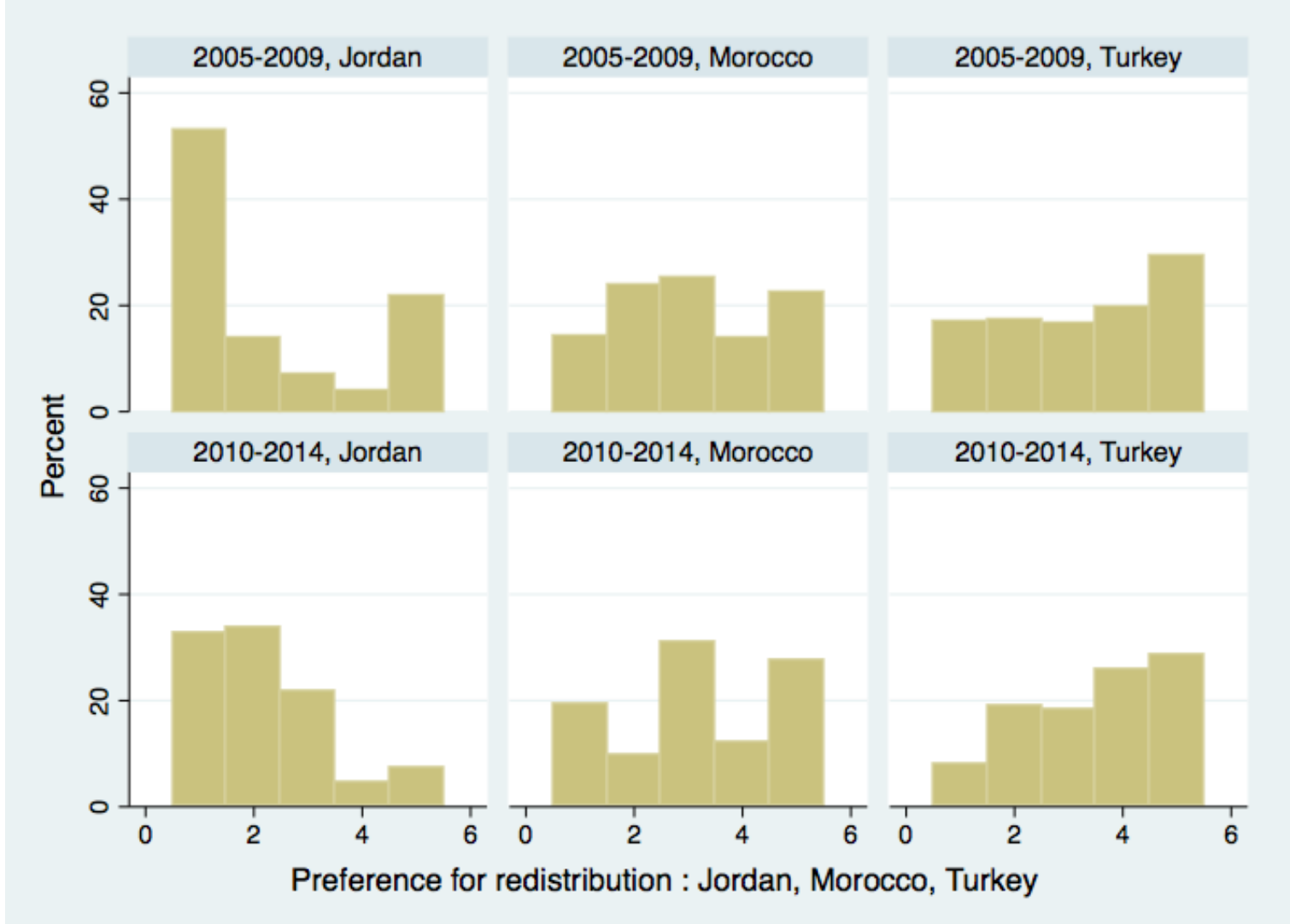

Figure 3: Preferences for redistribution before and after January 2011 : Jordan, Morocco, and Turkey

Table 11: Percentages of individuals who are favorable to redistribution before and after 2011

\begin{tabular}{lcc}
\hline & \% Individuals favorable for redistribution \\
\hline & $2007-2008$ & $2011-2014$ \\
\hline Egypt & $22 \%$ & $59 \%$ \\
Jordan & $25 \%$ & $12 \%$ \\
Morocco & $36 \%$ & $40 \%$ \\
Turkey & $49 \%$ & $55 \%$ \\
Algeria & - & $22 \%$ \\
Iraq & $39 \%$ & $38 \%$ \\
Kuwait & - & $23 \%$ \\
Lebanon & - & $30 \%$ \\
Libya & - & $22 \%$ \\
Palestine & - & $26 \%$ \\
Qatar & - & $18 \%$ \\
Tunisia & - & $22 \%$ \\
Yemen & - & $25 \%$ \\
\hline
\end{tabular}




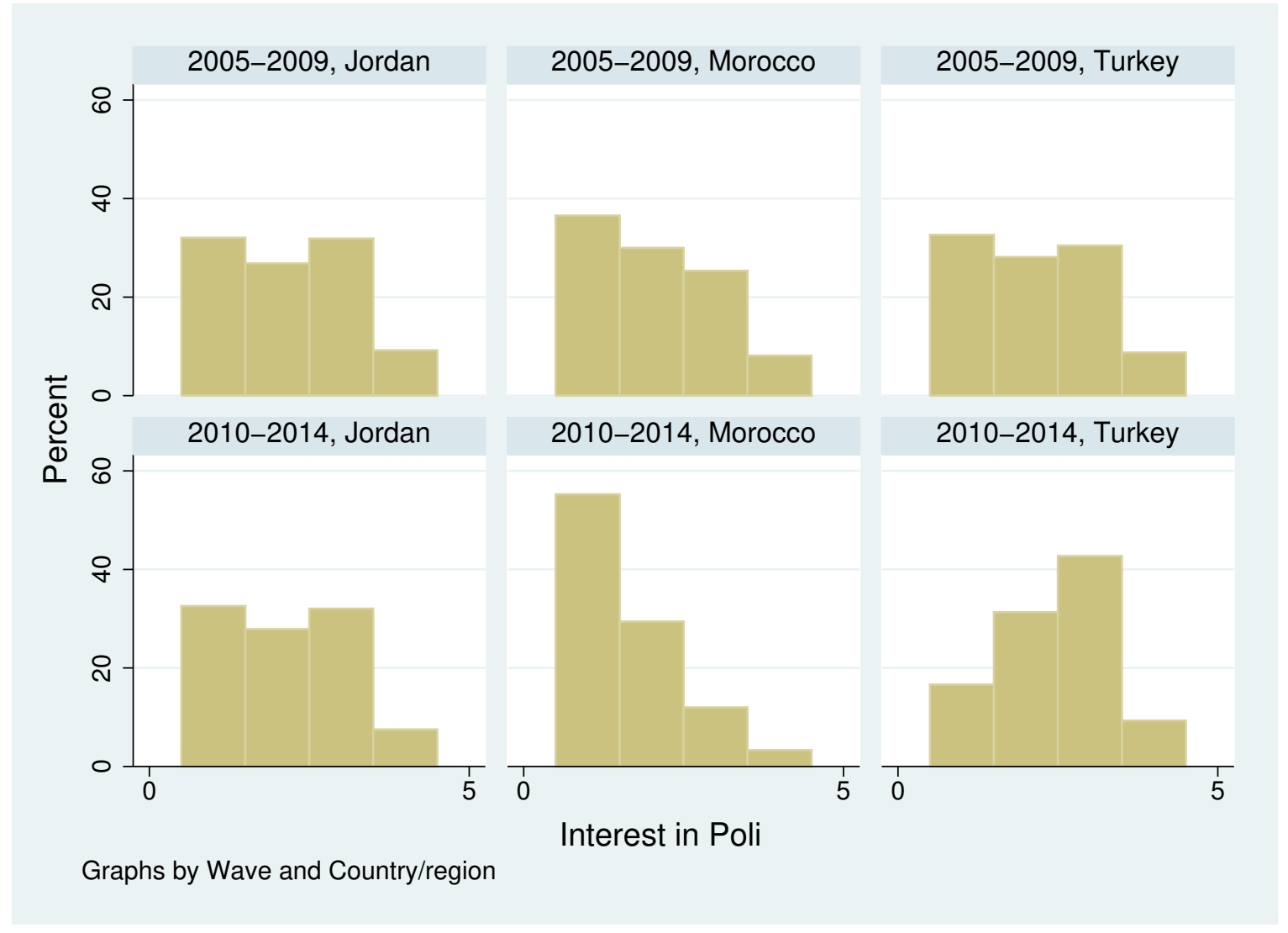

Figure 4: Interest in Politics before and after January 2011 : Jordan, Morocco, and Turkey 


\section{Annexe 4 : Regression Tables: Determinants for redistribution and Effect of revolution in Egypt}

Table 12: Determinants of preferences for redistribution and Effect of time in Egypt 1

\begin{tabular}{|c|c|c|c|c|c|c|}
\hline & $\begin{array}{c}(1) \\
\text { Pref for redi }\end{array}$ & $\begin{array}{c}(2) \\
\text { Pref for redi }\end{array}$ & $\begin{array}{c}(3) \\
\text { Pref for redi }\end{array}$ & $\begin{array}{c}(4) \\
\text { Pref for redi }\end{array}$ & $\begin{array}{l}(5) \\
\text { Pref for redi }\end{array}$ & $\begin{array}{c}(6) \\
\text { Pref for redi }\end{array}$ \\
\hline \multicolumn{7}{|l|}{ Pref for redis } \\
\hline After revolution & $1.497^{* * *}$ & $1.499^{* * *}$ & $1.491^{* * *}$ & $1.498^{* * *}$ & $1.482^{* * *}$ & $1.535^{* * *}$ \\
\hline Age $=1$ & & 0 & 0 & 0 & 0 & 0 \\
\hline Age $=2$ & & $0.160^{*}$ & $0.167^{* *}$ & 0.129 & $0.168^{*}$ & 0.125 \\
\hline Age $=3$ & & 0.136 & $0.158^{*}$ & 0.0454 & 0.0908 & 0.0682 \\
\hline Age $=4$ & & $0.333^{* * *}$ & $0.362^{* * *}$ & $0.255^{* *}$ & $0.288^{* * *}$ & $0.281^{* *}$ \\
\hline Woman & & & $0.147^{* * *}$ & 0.0946 & $0.104^{*}$ & $0.143^{* *}$ \\
\hline Education $=1$ & & & & 0 & 0 & 0 \\
\hline Education $=2$ & & & & $-0.260^{* * *}$ & $-0.262^{* * *}$ & $-0.222^{* * *}$ \\
\hline Education $=3$ & & & & $-0.211^{* *}$ & $-0.210^{* *}$ & $-0.191^{* *}$ \\
\hline Education $=4$ & & & & $-0.300^{* * *}$ & $-0.306^{* * *}$ & $-0.184^{* *}$ \\
\hline Children & & & & & -0.0986 & -0.103 \\
\hline Finan $\operatorname{sit}=1$ & & & & & & 0 \\
\hline Finan $\mathrm{sit}=2$ & & & & & & $0.199^{* *}$ \\
\hline Finan $\mathrm{sit}=3$ & & & & & & 0.0823 \\
\hline Finan sit $=4$ & & & & & & $-0.492^{* * *}$ \\
\hline Finan sit $=5$ & & & & & & $-0.832^{* * *}$ \\
\hline Observations & 4465 & 4465 & 4465 & 4305 & 4305 & 4304 \\
\hline Pseudo $R^{2}$ & 0.044 & 0.045 & 0.045 & 0.046 & 0.046 & 0.056 \\
\hline
\end{tabular}


Table 13: Determinants of preferences for redistribution and Effect of time in Egypt 2

\begin{tabular}{|c|c|c|c|c|c|}
\hline & $\begin{array}{c}(1) \\
\text { Pref for redis }\end{array}$ & $\begin{array}{c}(2) \\
\text { Pref for redis }\end{array}$ & $\begin{array}{c}(3) \\
\text { Pref for redis }\end{array}$ & $\begin{array}{c}(4) \\
\text { Pref for redis }\end{array}$ & $\begin{array}{c}(5) \\
\text { Pref for redis }\end{array}$ \\
\hline \multicolumn{6}{|l|}{ Pref for redis } \\
\hline After revolution & $1.508^{* * *}$ & $1.639^{* * *}$ & $1.535^{* * *}$ & $1.560^{* * *}$ & $1.547^{* * *}$ \\
\hline badhealth & $0.244^{* * *}$ & & & & \\
\hline Politic ideo $=1$ & & 0 & & & \\
\hline Politic ideo $=2$ & & -0.0154 & & & \\
\hline Politic ideo $=3$ & & $-0.247^{* * *}$ & & & \\
\hline Trust people & & & $0.454^{* * *}$ & & \\
\hline Religious & & & & $0.245^{* * *}$ & \\
\hline Risk attitude $=1$ & & & & & 0 \\
\hline Risk attitude $=2$ & & & & & -0.0288 \\
\hline Risk attitude $=3$ & & & & & -0.0373 \\
\hline Control variables & Group B & Group B & Group B & Group B & Group B \\
\hline Observations & 4304 & 4015 & 4299 & 4301 & 4281 \\
\hline Pseudo $R^{2}$ & 0.057 & 0.062 & 0.059 & 0.057 & 0.056 \\
\hline
\end{tabular}

${ }^{*} p<0.10,{ }^{* *} p<0.05,{ }^{* * *} p<0.01$

Group B : Age, Woman, Education, Children, Finan sit 
Table 14: Determinants of preferences for redistribution and Effect of time in Egypt 3

(1) (2) (3) (4)

Pref for redis Pref for redis Pref for redis Pref for redis

\begin{tabular}{|c|c|c|c|c|}
\hline \multicolumn{5}{|l|}{ Pref for redis } \\
\hline \multicolumn{5}{|l|}{$\begin{array}{l}\text { Pref for redis } \\
\text { After revolution }\end{array}$} \\
\hline Imp of Help $=1$ & 0 & & & \\
\hline Imp of Help $=2$ & $-0.297^{* *}$ & & & \\
\hline Imp of Help $=3$ & $-0.481^{* * *}$ & & & \\
\hline childaltruisme & & $-0.183^{* * *}$ & & \\
\hline Interest in Poli $=1$ & & & 0 & \\
\hline Interest in Poli $=2$ & & & 0.0152 & \\
\hline Interest in Poli $=3$ & & & $-0.204^{* * *}$ & \\
\hline Interest in Poli $=4$ & & & $0.334^{* * *}$ & \\
\hline Role of effort $=1$ & & & & 0 \\
\hline Role of effort $=2$ & & & & $-0.166^{* *}$ \\
\hline Role of effort $=3$ & & & & $-0.533^{* * *}$ \\
\hline Control variables & Group B & Group B & Group B & Group B \\
\hline Observations & 4300 & 4304 & 4301 & 4300 \\
\hline Pseudo $R^{2}$ & 0.057 & 0.057 & 0.058 & 0.061 \\
\hline
\end{tabular}

${ }^{*} p<0.10,{ }^{* *} p<0.05,{ }^{* * *} p<0.01$ 


\section{Diff-in-Diff analysis}

Table 15: Effect of time in Egypt, Jordan, Morocco, and Turkey

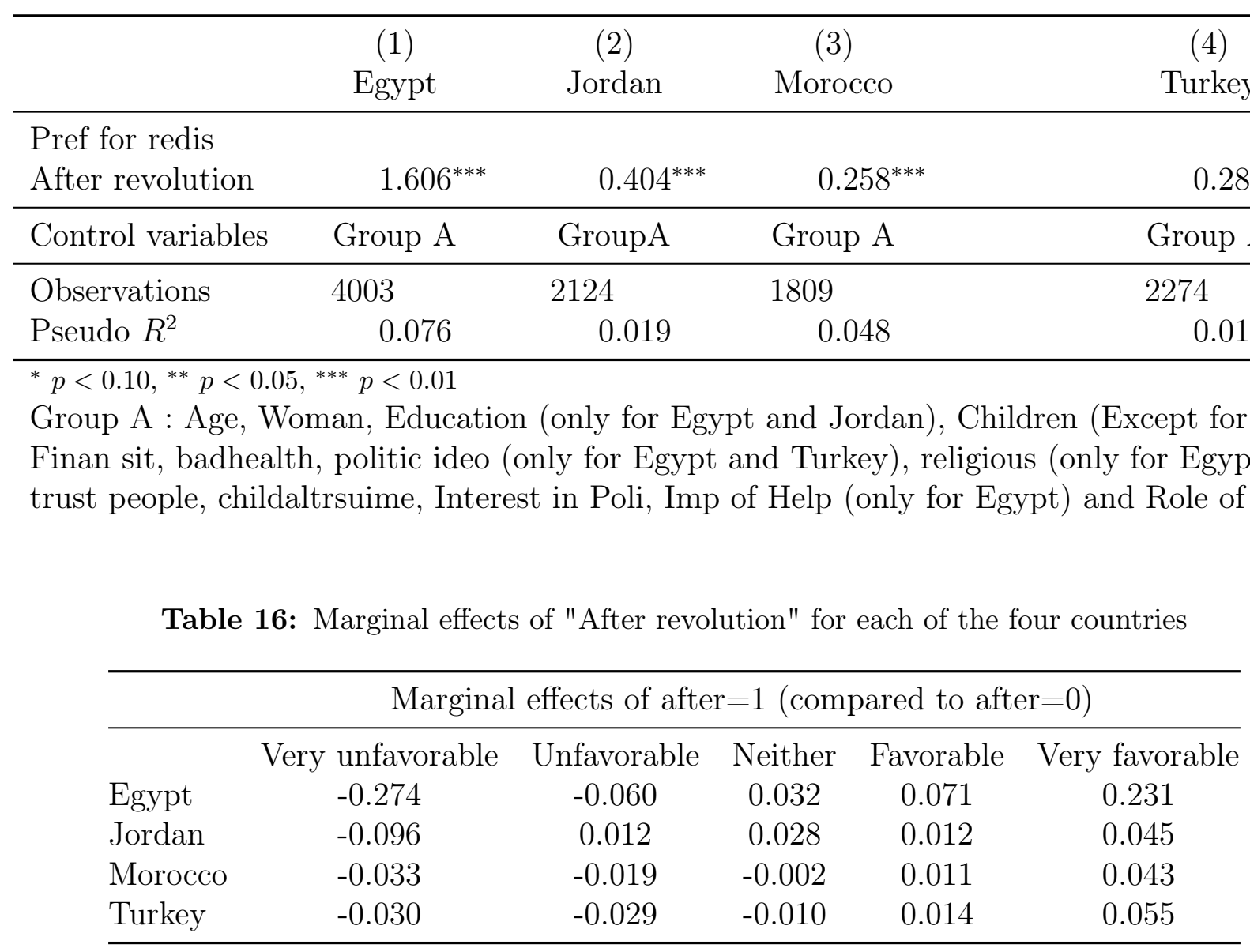


Table 17: Diff in Diff : Egypt and each one of the countries

\begin{tabular}{lccc}
\hline & $\begin{array}{c}(1) \\
\text { Egy*Jordan }\end{array}$ & $\begin{array}{c}(2) \\
\text { Egy*Morroco }\end{array}$ & $\begin{array}{c}(3) \\
\text { Egy*Turkey }\end{array}$ \\
\hline Pref for redis & & & \\
After revolution $=0$ & 0 & 0 & 0 \\
After revolution=1 & $0.330^{* * *}$ & $0.188^{* *}$ & $0.244^{* * *}$ \\
Egypte $=0$ & 0 & 0 & 0 \\
Egypte $=1$ & $0.353^{* * *}$ & $-0.803^{* * *}$ & $-1.448^{* * *}$ \\
After revolution $=0 \times$ Egypte $=0$ & 0 & 0 & 0 \\
After revolution $=0 \times$ Egypte $=1$ & 0 & 0 & 0 \\
After revolution $=1 \times$ Egypte $=0$ & 0 & 0 & 0 \\
After revolution $=1 \times$ Egypte $=1$ & $1.150^{* * *}$ & $1.348^{* * *}$ & $1.393^{* * *}$ \\
\hline Control variables & Group A & Group A & Group A \\
\hline Observations & 6416 & 6075 & 6437 \\
Pseudo $R^{2}$ & 0.056 & 0.059 & 0.060 \\
\hline
\end{tabular}

${ }^{*} p<0.10,{ }^{* *} p<0.05,{ }^{* * *} p<0.01$

Group A : Age, Woman, Education (only for Egypt and Jordan), Children (Except for Morocco), Finan sit, badhealth, politic ideo (only for Egypt and Turkey), religious (only for Egypt and Turkey), trust people, childaltrsuime, Interest in Poli, Imp of Help (only for Egypt) and Role of effort.

Table 18: Diff in Diff : Egypt and the other three countries

\begin{tabular}{lcc}
\hline & $\begin{array}{c}(1) \\
\text { Pref for redis }\end{array}$ & $\begin{array}{c}(2) \\
\text { Pref for redis }\end{array}$ \\
\hline Pref for redis & & \\
After revolution $=0$ & 0 & 0 \\
After revolution $=1$ & $0.598^{* * *}$ & $0.167^{* * *}$ \\
egypte $=0$ & 0 & 0 \\
egypte $=1$ & $-0.152^{* * *}$ & $-0.627^{* * *}$ \\
After revolution $=0 \times$ egypte $=0$ & & 0 \\
After revolution $=0 \times$ egypte $=1$ & & 0 \\
After revolution $=1 \times$ egypte $=0$ & & 0 \\
After revolution $=1 \times$ egypte $=1$ & & $1.274^{* * *}$ \\
\hline Control variables & Group C & Group C \\
\hline Observations & 10896 & 10896 \\
Pseudo $R^{2}$ & 0.023 & 0.031 \\
\hline
\end{tabular}

${ }^{*} p<0.10,{ }^{* *} p<0.05,{ }^{* * *} p<0.01$

Group C : Age, Woman, Children, Finan sit, badhealth, trust people, childaltrsuime, Interest in Poli and Role of effort. 
Table 19: Effect of time for the periods 2001-2008 and 2008-2012 in Egypt

\begin{tabular}{lcc}
\hline & $(1)$ & $(2)$ \\
& $2001-2008$ & $2008-2012$ \\
\hline Pref for redis & & \\
Between 2001 and 2008 & $1.027^{* * *}$ & $1.606^{* * *}$ \\
Between 2008 and 2012 & & 4003 \\
\hline Observations & 5664 & 0.076 \\
Pseudo $R^{2}$ & 0.046 & \\
${ }^{*} p<0.10,{ }^{* *} p<0.05,{ }^{* * *} p<0.01$ & \\
Controls include : Group of variables B except Politic ideo and Imp of Help for the period 2001-2008
\end{tabular}

Table 20: Marginal effects of the time variable between 2001 and 2008, and between 2008 and 2012

\begin{tabular}{cccccc}
\hline \multicolumn{5}{c}{ Marginal effects of the time variable } \\
\hline & Very unfavorable & Unfavorable & Neither & Favorable & Very favorable \\
$2000-2008$ & -0.227 & 0.043 & 0.067 & 0.053 & 0.063 \\
$2008-2012$ & -0.274 & -0.060 & 0.032 & 0.071 & 0.231 \\
\hline
\end{tabular}




\section{Annexe 5 : Heterogeneous effects of the revolution in Egypt}

Table 21: Differential Effect : Interactions between revolution and financial and health situation groups

(1)

$(2)$

Pref for redis Pref for redis

Pref for redis

After revolution $=0$

After revolution $=1$

Finan sit $=1$

Finan sit $=2$

Finan sit $=3$

0

0

$2.259^{* * *}$

$1.423^{* * *}$

0

0

$0.386^{* * *}$

$0.231^{* * *}$

Finan sit $=4$

$0.403^{* * *}$

$0.174^{*}$

Finan sit $=5$

After revolution $=0 \times$ Finan sit $=1$

$-0.00990$

$-0.313^{* * *}$

After revolution $=0 \times$ Finan sit $=2$

$-0.348^{* *}$

$-0.765^{* * *}$

After revolution $=0 \times$ Finan sit $=3$

0

0

After revolution $=0 \times$ Finan sit $=4$

0

After revolution $=0 \times$ Finan sit $=5$

0

After revolution $=1 \times$ Finan sit $=1$

0

After revolution $=1 \times$ Finan sit $=2$

0

After revolution $=1 \times$ Finan sit $=3$

$-0.474^{* *}$

After revolution $=1 \times$ Finan sit $=4$

$-0.764^{* * *}$

$-0.976^{* * *}$

After revolution $=1 \times$ Finan sit $=5$

$-1.375^{* * *}$

badhealth

$0.214^{* * *}$

badhealth $=0$

0

badhealth $=1$

After revolution $=0 \times$ badhealth $=0$

0

After revolution $=0 \times$ badhealth $=1$

0

After revolution $=1 \times$ badhealth $=0$

0

After revolution $=1 \times$ badhealth $=1$

$0.489^{* * *}$

\begin{tabular}{lcc}
\hline Observations & 4003 & 4003 \\
Pseudo $R^{2}$ & 0.080 & 0.077 \\
\hline
\end{tabular}

Controls include: Group of variables A.

${ }^{*} p<0.10,{ }^{* *} p<0.05,{ }^{* * *} p<0.01$ 
Table 22: Effect of revolution in Egypt over the financial situation groups

\begin{tabular}{lcccc}
\hline & $(1)$ & $(2)$ & $(3)$ & $(4)$ \\
& All & Difficult financial situation & Average fin sit & Very good fin sit \\
Pref for redis & & & & $1.740^{* * *}$ \\
After revolution & $1.606^{* * *}$ & $1.944^{* * *}$ & 1423 & $1.356^{* * *}$ \\
\hline Observations & 4003 & 1358 & 0.077 & 1222 \\
Pseudo $R^{2}$ & 0.076 & 0.102 & & 0.052 \\
\hline
\end{tabular}

Controls include: Group of variables A.

${ }^{*} p<0.10,{ }^{* *} p<0.05,{ }^{* * *} p<0.01$ 
Table 23: Differential Effect : Interactions between revolution and degree of interest in politics and age groups

$(1)$

Pref for redis Pref for redis

\begin{tabular}{|c|c|c|}
\hline \multicolumn{3}{|l|}{ Pref for redis } \\
\hline After revolution $=0$ & 0 & 0 \\
\hline After revolution $=1$ & $1.484^{* * *}$ & $1.302^{* * *}$ \\
\hline Interest in Poli $=1$ & 0 & 0 \\
\hline Interest in Poli $=2$ & 0.0614 & 0.0454 \\
\hline Interest in $\mathrm{Poli}=3$ & -0.135 & $-0.138^{*}$ \\
\hline Interest in $\mathrm{Poli}=4$ & -0.0631 & $0.371^{* * *}$ \\
\hline After revolution $=0 \times$ Interest in Poli $=1$ & 0 & \\
\hline After revolution $=0 \times$ Interest in Poli $=2$ & 0 & \\
\hline After revolution $=0 \times$ Interest in Poli $=3$ & 0 & \\
\hline After revolution $=0 \times$ Interest in Poli $=4$ & 0 & \\
\hline After revolution $=1 \times$ Interest in Poli $=1$ & 0 & \\
\hline After revolution $=1 \times$ Interest in Poli $=2$ & -0.0260 & \\
\hline After revolution $=1 \times$ Interest in Poli $=3$ & 0.0685 & \\
\hline After revolution $=1 \times$ Interest in Poli $=4$ & $0.706^{* * *}$ & \\
\hline Age $=1$ & 0 & 0 \\
\hline Age $=2$ & 0.101 & -0.0404 \\
\hline Age $=3$ & 0.0190 & -0.0936 \\
\hline Age $=4$ & 0.144 & 0.0381 \\
\hline After revolution $=0 \times$ Age $=1$ & & 0 \\
\hline After revolution $=0 \times$ Age $=2$ & & 0 \\
\hline After revolution $=0 \times$ Age $=3$ & & 0 \\
\hline After revolution $=0 \times$ Age $=4$ & & 0 \\
\hline After revolution $=1 \times$ Age $=1$ & & 0 \\
\hline After revolution $=1 \times$ Age $=2$ & & $0.431^{* *}$ \\
\hline After revolution $=1 \times$ Age $=3$ & & $0.340^{*}$ \\
\hline After revolution $=1 \times$ Age $=4$ & & 0.312 \\
\hline Observations & 4003 & 4003 \\
\hline Pseudo $R^{2}$ & 0.077 & 0.077 \\
\hline
\end{tabular}

Controls include: Group of variables A.

${ }^{*} p<0.10,{ }^{* *} p<0.05,{ }^{* * *} p<0.01$ 


\title{
Annexe 6 : Determinants of demand for redistribution in the Middle east and the North Africa: Comparison
}

\author{
Risk attitude
}

Table 24: Coefficients regressions for risk attitude 1

\begin{tabular}{lcccc}
\hline & $(1)$ & $(2)$ & $(3)$ & $(4)$ \\
& Egypte & Algerie & Iran & Bahrain \\
\hline Pref for redis & & & & \\
Risk attitude $=1$ & 0 & 0 & 0 & 0 \\
Risk attitude $=2$ & -0.0288 & $0.561^{* * *}$ & $-0.256^{* * *}$ & $0.530^{* * *}$ \\
Risk attitude $=3$ & -0.0373 & $0.448^{* * *}$ & $-0.335^{* * *}$ & $0.414^{* * *}$ \\
\hline Observations & 4281 & 977 & 2208 & 1051 \\
Pseudo $R^{2}$ & 0.056 & 0.029 & 0.007 & 0.021 \\
\hline
\end{tabular}

${ }^{*} p<0.10,{ }^{* *} p<0.05,{ }^{* * *} p<0.01$

Controls include: Group of variables B.

Table 25: Coefficients regressions for risk attitude 2

\begin{tabular}{lcccc}
\hline & $\begin{array}{c}(5) \\
\text { Maroc }\end{array}$ & $\begin{array}{c}(6) \\
\text { Jordanie }\end{array}$ & $\begin{array}{c}(7) \\
\text { Lebanon }\end{array}$ & $\begin{array}{c}(8) \\
\text { Libya }\end{array}$ \\
\hline Pref for redis & & & & \\
Risk attitude $=1$ & 0 & 0 & 0 & 0 \\
Risk attitude=2 & -0.0908 & $0.179^{*}$ & $0.327^{* *}$ & 0.0181 \\
Risk attitude=3 & -0.221 & 0.116 & $0.423^{* * *}$ & -0.116 \\
\hline Observations & 1139 & 2120 & 1032 & 1865 \\
Pseudo $R^{2}$ & 0.036 & 0.010 & 0.011 & 0.019 \\
\hline${ }^{*} p<0.10,{ }^{* *} p<0.05,{ }^{* * *} p<0.01$ & & \\
Controls include: Group of variables B.
\end{tabular}


Table 26: Coefficients regressions for risk attitude 3

\begin{tabular}{lcccc}
\hline & $(9)$ & $(10)$ & $(11)$ & $(12)$ \\
& Palestine & Tunisia & Yemen & Turkey \\
\hline Pref for redis & & & & \\
Risk attitude $=1$ & 0 & 0 & 0 & 0 \\
Risk attitude $=2$ & 0.138 & 0.0715 & $0.478^{* * *}$ & $-0.309^{* * *}$ \\
Risk attitude $=3$ & 0.0295 & -0.0156 & 0.256 & $-0.322^{* * *}$ \\
\hline Observations & 913 & 980 & 828 & 2615 \\
Pseudo $R^{2}$ & 0.012 & 0.020 & 0.029 & 0.010 \\
\hline
\end{tabular}

${ }^{*} p<0.10,{ }^{* *} p<0.05,{ }^{* * *} p<0.01$

Controls include: Group of variables B.

\section{Attend religious services}

Table 27: Coefficients regressions for religion 1

\begin{tabular}{lccccc}
\hline & $(1)$ & $(2)$ & $(3)$ & $(4)$ & $(5)$ \\
& Egypte & Algerie & Iraq & Iran & Bahrain \\
\hline $\begin{array}{l}\text { Pref for redis } \\
\text { Religious }\end{array}$ & $0.245^{* * *}$ & 0.125 & $0.184^{* *}$ & 0.00130 & 0.154 \\
\hline $\begin{array}{l}\text { Observations } \\
\text { Pseudo } R^{2}\end{array}$ & 4301 & 1042 & 2782 & 2113 & 1053 \\
\hline
\end{tabular}

${ }^{*} p<0.10,{ }^{* *} p<0.05,{ }^{* * *} p<0.01$

Controls include: Group of variables B. 
Table 28: Coefficients regressions for religion 2

\begin{tabular}{lcccc}
\hline & $\begin{array}{c}(6) \\
\text { Maroc }\end{array}$ & $\begin{array}{c}(7) \\
\text { Jordanie }\end{array}$ & $\begin{array}{c}(8) \\
\text { Lebanon }\end{array}$ & $\begin{array}{c}(9) \\
\text { Libya }\end{array}$ \\
\hline $\begin{array}{l}\text { Pref for redis } \\
\text { Religious }\end{array}$ & 0.334 & -0.0606 & $0.298^{* * *}$ & -0.110 \\
\hline Observations & 356 & 1115 & 1053 & 1753 \\
Pseudo $R^{2}$ & 0.073 & 0.008 & 0.010 & 0.020 \\
\hline${ }^{*} p<0.10,{ }^{* *} p<0.05,{ }^{* * *} p<0.01$ & & \\
Controls include: Group of variables B. & &
\end{tabular}

Table 29: Coefficients regressions for religion 3

\begin{tabular}{lcccc}
\hline & $(10)$ & $(11)$ & $(12)$ & $(13)$ \\
& Palestine & Tunisia & Yemen & Turkey \\
\hline Pref for redis & & & & \\
Religious & $-0.249^{*}$ & $-0.298^{* *}$ & -0.103 & -0.0728 \\
\hline Observations & 931 & 1025 & 848 & 2617 \\
Pseudo $R^{2}$ & 0.012 & 0.023 & 0.026 & 0.008 \\
\hline
\end{tabular}

${ }^{*} p<0.10,{ }^{* *} p<0.05,{ }^{* * *} p<0.01$

Controls include: Group of variables B. 


\section{Important child qualities: unselfishness (Altruism)}

Table 30: Coefficients regressions for child altruisme 1

\begin{tabular}{lccccc}
\hline & $(1)$ & $(2)$ & $(3)$ & $(4)$ & $(5)$ \\
& Egypte & Algerie & Iraq & Iran & Bahrain \\
\hline $\begin{array}{l}\text { Pref for redis } \\
\text { childaltruisme }\end{array}$ & $-0.183^{* * *}$ & -0.0921 & $-0.303^{* * *}$ & 0.0178 & 0.0817 \\
\hline Observations & 4304 & 1042 & 3091 & 2219 & 1053 \\
Pseudo $R^{2}$ & 0.057 & 0.029 & 0.012 & 0.005 & 0.017 \\
\hline
\end{tabular}

${ }^{*} p<0.10,{ }^{* *} p<0.05,{ }^{* * *} p<0.01$

Controls include: Group of variables B.

Table 31: Coefficients regressions for child altruisme 2

\begin{tabular}{lccccc}
\hline & $(6)$ & $(7)$ & $(8)$ & $(9)$ & $(10)$ \\
& Maroc & Jordanie & Lebanon & Kuwait & Libya \\
\hline $\begin{array}{l}\text { Pref for redis } \\
\text { childaltruisme }\end{array}$ & 0.0662 & $0.252^{* * *}$ & $-0.391^{* * *}$ & -0.122 & -0.0145 \\
\hline $\begin{array}{l}\text { Observations } \\
\text { Pseudo } R^{2}\end{array}$ & 1192 & 2133 & 1053 & 1129 & 1928 \\
\hline
\end{tabular}

${ }^{*} p<0.10,{ }^{* *} p<0.05,{ }^{* * *} p<0.01$

Controls include: Group of variables B. 
Table 32: Coefficients regressions for child altruisme 3

\begin{tabular}{lccccc}
\hline & $(11)$ & $(12)$ & $(13)$ & $(14)$ & $(15)$ \\
& Palestine & Qatar & Tunisia & Yemen & Turkey \\
\hline $\begin{array}{l}\text { Pref for redis } \\
\text { childaltruisme }\end{array}$ & -0.202 & -0.0629 & $-0.350^{* * *}$ & $0.420^{* * *}$ & 0.0861 \\
\hline Observations & 931 & 975 & 1025 & 864 & 2664 \\
Pseudo $R^{2}$ & 0.012 & 0.010 & 0.024 & 0.029 & 0.008 \\
\hline
\end{tabular}

${ }^{*} p<0.10,{ }^{* *} p<0.05,{ }^{* * *} p<0.01$

Controls include: Group of variables B.

\section{The importance of helping others (Altruism)}

Table 33: Coefficients regressions for help al 1

\begin{tabular}{lcccc}
\hline & $\begin{array}{c}(1) \\
\text { Egypte }\end{array}$ & $\begin{array}{c}(2) \\
\text { Algerie }\end{array}$ & $\begin{array}{c}(3) \\
\text { Iraq }\end{array}$ & $\begin{array}{c}(4) \\
\text { Bahrain }\end{array}$ \\
\hline Pref for redis & & & & \\
Imp of Help $=1$ & 0 & 0 & 0 & 0 \\
Imp of Help $=2$ & $-0.297^{* *}$ & $0.522^{* *}$ & -0.328 & 0.272 \\
Imp of Help $=3$ & $-0.481^{* * *}$ & 0.0214 & 0.0576 & 0.331 \\
\hline Observations & 4300 & 998 & 1114 & 1048 \\
Pseudo $R^{2}$ & 0.057 & 0.035 & 0.017 & 0.017 \\
\hline
\end{tabular}

${ }^{*} p<0.10,{ }^{* *} p<0.05,{ }^{* * *} p<0.01$

Controls include: Group of variables B. 
Table 34: Coefficients regressions for help al 2

\begin{tabular}{lccccc}
\hline & $(5)$ & $(6)$ & $(7)$ & $(8)$ & $(9)$ \\
& Maroc & Jordanie & Lebanon & Kuwait & Libya \\
\hline Pref for redis & & & & & \\
Imp of Help $=1$ & 0 & 0 & 0 & 0 & 0 \\
Imp of Help $=2$ & -0.145 & -0.218 & $-0.342^{* *}$ & -0.297 & -0.321 \\
Imp of Help $=3$ & -0.213 & $-0.797^{* *}$ & $-0.525^{* * *}$ & $-0.438^{*}$ & $-0.481^{* *}$ \\
\hline Observations & 1173 & 2121 & 1039 & 1105 & 1895 \\
Pseudo $R^{2}$ & 0.036 & 0.015 & 0.010 & 0.017 & 0.020 \\
\hline
\end{tabular}

${ }^{*} p<0.10,{ }^{* *} p<0.05,{ }^{* * *} p<0.01$

Controls include: Group of variables B.

Table 35: Coefficients regressions for help al 3

\begin{tabular}{lcccc}
\hline & $\begin{array}{c}(10) \\
\text { Palestine }\end{array}$ & $\begin{array}{c}(11) \\
\text { Tunisia }\end{array}$ & $\begin{array}{c}(12) \\
\text { Yemen }\end{array}$ & $\begin{array}{c}(13) \\
\text { Turkey }\end{array}$ \\
\hline Pref for redis & & & & \\
Imp of Help=1 & 0 & 0 & 0 & 0 \\
Imp of Help=2 & $-0.721^{* *}$ & 0.319 & 0.0221 & -0.495 \\
Imp of Help=3 & $-0.728^{* * *}$ & $0.655^{* *}$ & $-0.800^{* *}$ & -0.516 \\
\hline Observations & 915 & 989 & 848 & 1153 \\
Pseudo $R^{2}$ & 0.014 & 0.023 & 0.036 & 0.006 \\
\hline
\end{tabular}

${ }^{*} p<0.10,{ }^{* *} p<0.05,{ }^{* * *} p<0.01$

Controls include: Group of variables B. 


\section{Autonomy freedom (Perception of the role of effort)}

Table 36: Coefficients regressions for Choice and control (Fairness) 1

\begin{tabular}{lccccc}
\hline & $(1)$ & $(2)$ & $(3)$ & $(4)$ & $(5)$ \\
& Egypte & Algerie & Iraq & Iran & Bahrain \\
\hline Pref for redis & & & & & \\
Role of effort=1 & 0 & 0 & 0 & 0 & 0 \\
Role of effort=2 & $-0.166^{* *}$ & $0.851^{* * *}$ & -0.126 & $-0.236^{*}$ & -0.0565 \\
Role of effort=3 & $-0.533^{* * *}$ & $0.390^{* *}$ & $-0.245^{* * *}$ & -0.0191 & -0.193 \\
\hline Observations & 4300 & 1025 & 3075 & 2213 & 1047 \\
Pseudo $R^{2}$ & 0.061 & 0.036 & 0.012 & 0.006 & 0.017 \\
\hline$*$
\end{tabular}

${ }^{*} p<0.10,{ }^{* *} p<0.05,{ }^{* * *} p<0.01$

Controls include: Group of variables B.

Table 37: Coefficients regressions for Choice and control (Fairness) 2

\begin{tabular}{lccccc}
\hline & $\begin{array}{c}(6) \\
\text { Maroc }\end{array}$ & $\begin{array}{c}(7) \\
\text { Jordanie }\end{array}$ & $\begin{array}{c}(8) \\
\text { Lebanon }\end{array}$ & $\begin{array}{c}(9) \\
\text { Kuwait }\end{array}$ & $\begin{array}{c}(10) \\
\text { Libya }\end{array}$ \\
\hline Pref for redis & & & & & \\
Role of effort=1 & 0 & 0 & 0 & 0 & 0 \\
Role of effort=2 & $-1.066^{* * *}$ & 0.0714 & 0.294 & 0.273 & -0.159 \\
Role of effort=3 & $-1.076^{* * *}$ & $-0.493^{* * *}$ & -0.0576 & 0.203 & $-0.331^{* *}$ \\
\hline Observations & 1135 & 2131 & 1051 & 1111 & 1899 \\
Pseudo $R^{2}$ & 0.046 & 0.017 & 0.011 & 0.016 & 0.021 \\
\hline
\end{tabular}

${ }^{*} p<0.10,{ }^{* *} p<0.05,{ }^{* * *} p<0.01$

Controls include: Group of variables B. 
Table 38: Coefficients regressions for Choice and control (Fairness) 3

\begin{tabular}{lccccc}
\hline & $\begin{array}{c}(11) \\
\text { Palestine }\end{array}$ & $\begin{array}{c}(12) \\
\text { Qatar }\end{array}$ & $\begin{array}{c}(13) \\
\text { Tunisia }\end{array}$ & $\begin{array}{c}(14) \\
\text { Yemen }\end{array}$ & $\begin{array}{c}(15) \\
\text { Turkey }\end{array}$ \\
\hline Pref for redis & & & & & \\
Role of effort $=1$ & 0 & 0 & 0 & 0 & 0 \\
Role of effort $=2$ & -0.328 & -0.196 & $-0.908^{* * *}$ & -0.145 & $-0.311^{* *}$ \\
Role of effort=3 & -0.235 & $-0.441^{*}$ & $-1.226^{* * *}$ & $-0.557^{* * *}$ & $-0.448^{* * *}$ \\
\hline Observations & 927 & 975 & 1011 & 838 & 2642 \\
Pseudo $R^{2}$ & 0.012 & 0.011 & 0.035 & 0.030 & 0.010 \\
\hline
\end{tabular}

${ }^{*} p<0.10,{ }^{* *} p<0.05,{ }^{* * *} p<0.01$

Controls include: Group of variables B. 